2 Research Square
Preprints are preliminary reports that have not undergone peer review.

They should not be considered conclusive, used to inform clinical practice, or referenced by the media as validated information.

\title{
Intervention programs targeting the mental health, professional burnout, or wellbeing of school teachers: A systematic review and meta-analyses
}

Joanne Beames ( $\boldsymbol{D}$ j.beames@blackdog.org.au )

Black Dog Institute, University of New South Wales, Sydney, NSW https://orcid.org/0000-0003-3630-0980

Samantha Spanos

Black Dog Institute, University of New South Wales, Sydney, NSW

Anna Roberts

Black Dog Institute, University of New South Wales, Sydney, NSW

Lauren McGillivray

Black Dog Institute, University of New South Wales, Sydney, NSW

Sophie Li

Black Dog Institute and School of Psychology, University of New South Wales, Sydney, NSW

Jill Newby

Black Dog Institute and School of Psychology, University of New South Wales, Sydney, NSW

Bridianne O'Dea

Black Dog Institute, University of New South Wales, Sydney, NSW

Aliza Werner-Seidler

Black Dog Institute, University of New South Wales, Sydney, NSW

Research Article

Keywords: Teacher, Mental Health, Burnout, Wellbeing, Review, Meta-analysis

Posted Date: March 2nd, 2022

DOI: https://doi.org/10.21203/rs.3.rs-1386793/v1

License: @ (i) This work is licensed under a Creative Commons Attribution 4.0 International License. Read Full License 


\section{Abstract}

This paper outlines a systematic review and meta-analyses to identify, describe, and evaluate randomised and non-randomised controlled trials of psychological programs targeting the mental health, professional burnout, or wellbeing of school classroom teachers. Eighty-two unique studies were identified for inclusion in the review, and of those 39 were included in the meta-analyses (19 randomised controlled trials). In randomised controlled trials, the programs examined had significant large effects on stress ( $g=1.16)$, and moderate effects on burnout ( $g=0.58)$ and wellbeing ( $g=0.68)$. In non-randomised controlled trials, programs had significant moderate effects on stress $(g=0.62)$, and small to moderate effects on anxiety $(g=0.42)$, depression $(g=0.36)$, and wellbeing $(g=0.44)$. Studies were heterogeneous in design and methodological quality was generally poor, particularly in non-randomised controlled trials. There was an inadequate number of comparisons to perform sub-group analyses, meta-regression, or publication bias analyses. Most of the programs examined required significant time, effort, and resources to deliver and complete. These programs may not translate well outside of research trials to realworld contexts due to teachers being time poor. Priorities for research include using methodologically rigorous designs, developing programs for teachers with teachers (i.e., co-design), and considering implementation factors to ensure feasibility, acceptability, and uptake. Systematic Review Registration Number: PROPSERO - CRD42020159805.

\section{Introduction}

School teachers are a vulnerable workforce. International research shows that teachers consistently report burnout, psychological distress, anxiety, depression, fatigue, reduced self-confidence, and damaged personal relationships (García-Carmona et al., 2019; Thomson, 2020). The psychological toll on teachers has likely been exacerbated by the COVID-19 pandemic due to uncertainty around government regulations and school responsibilities, changes in ways of working, fears of exposure to COVID-19, and increased workloads (Beames et al., 2021; Ozamiz-Etxebarria, Idoiaga Mondragon, et al., 2021; Silva, Cobucci, et al., 2021; Steiner \& Woo, 2021; Vargas Rubilar \& Oros, 2021). Indeed, teachers have had to rapidly adapt to provide online classes and support for students when working from home during school shutdowns. Poor mental health, burnout, and low wellbeing have negative consequences for teacher performance and workforce retention, as well as for student learning and achievement (Alliance for Excellent Education, 2014; Gu \& Day, 2013; Howard \& Johnson, 2004; Jennings \& Greenberg, 2009; Miller et al., 2008; Ronfeldt et al., 2013; Sorensen \& Ladd, 2020). Finding ways to improve the psychological wellbeing of teachers is crucial to sustain and optimise the workforce, especially in response to large-scale adverse events that affect the school environment (e.g., pandemics, bushfires, school shootings).

There are a variety of programs that have been implemented to address teacher mental health, burnout, and wellbeing. Program types that have typically been delivered to teachers have included psychological approaches, such as psychoeducation, mindfulness, cognitive-behavioural skills, acceptance-based skills, behavioural stress management skills (e.g., relaxation), classroom management skills, and other socio-emotional/interpersonal skills. Two systematic reviews of randomised controlled trials (RCTs) and non-randomised controlled trials (nRCTs) examined a range of programs and psychological outcomes for school teachers at various education levels (e.g., elementary, middle, and secondary schools). The first review ( $k=24)$ found that mindfulness, behavioural, and cognitive-behavioural programs were effective in reducing stress and burnout (von der Embse et al., 2019). The second review ( $k=29)$ found that wellbeing programs were generally effective for teachers, especially positive psychology interventions and brief activities to provoke changes in thinking and feeling (Dreer \& Gouasé, 2021). Meta-analytic reviews have also provided promising results for mindfulness-based programs (Klingbeil \& Renshaw, 2018; Zarate et al., 2019) and burnout (e.g., burnout; lancu et al., 2018; Oliveira et al., 2021). The consensus in the literature is that programs for teacher mental health, burnout, and wellbeing can be effective, but there is wide variety in the intervention approaches used and level of methodological rigor adopted to evaluate them.

The available reviews, although promising, are limited in some respects. Past reviews have included programs designed to build classroom competencies or student wellbeing (e.g., behavioural classroom management, teacher consultation dyads, vocal health), with the rationale that the teachers who implement them may experience secondary mental health and wellbeing benefits (Dreer \& Gouasé, 2021; von der Embse et al., 2019). Programs for building classroom competencies are conceptually different to psychological programs that directly target teachers' thoughts, feelings, and responses to stressful situations. An in-depth examination of psychological programs for teachers is needed to describe what they involve and quantify how effectively they improve mental health, burnout, and wellbeing for the teaching workforce. There is also a lack of specificity about the teaching population under investigation. Past reviews generally used a broad definition of educators and school personnel, including teachers, counsellors/psychologists, principals, paraprofessionals, administration staff, pastoral carers and/or parents, and did not differentiate program effects between these groups (e.g., lancu et al., 2018; Klingbeil \& Renshaw, 2018; von der Embse et al., 2019). Focusing specifically on classroom teachers (i.e., those that have a primary responsibility for teaching) is important because they face role-specific challenges that influence appropriateness, uptake, and effectiveness of the programs designed specifically for their use.

There is a clear need for a comprehensive, methodologically rigorous approach to describe the whole suite of psychological programs empirically tested for teachers and answer questions about which are the most effective. The current systematic review and meta-analyses of psychological programs targeting mental health issues (i.e., anxiety, depression, stress, psychological distress, trauma, somatisation, sleep problems), burnout, and wellbeing in school classroom teachers directly addresses this gap.

\section{Aims}

The aim of the current review was to identify, describe, and evaluate controlled trials (both randomised and non-randomised) of psychological programs targeting the mental health, professional burnout, or wellbeing of school teachers. Including nRCTs is a strength of our approach. Given that a large proportion of studies in this field are non-randomised, their inclusion offers a wealth of information about available programs and their effectiveness in real-world contexts. Our approach extends the existing reviews in the field by evaluating a comprehensive range of programs and outcomes, as well as study designs, and focusing on programs for the teaching workforce. We also evaluate methodological rigor by using established tools to evaluate study quality and risk of bias of the included studies. 


\section{Methods}

\section{Protocol and Registration}

Consistent with Preferred Reporting Items for Systematic Reviews and Meta-Analyses (PRISMA) guidelines (Moher et al., 2009), this review was prospectively registered with PROSPERO on $27^{\text {th }}$ November 2019 (CRD42020159805).

\section{Systematic Review Eligibility Criteria}

Types of participants. Participants were teachers, from pre-service (i.e., teaching candidates pursuing formal qualifications/licences) to experienced levels, who had a primary responsibility for educating students (i.e., classroom teachers, special education teachers). Examples include early childhood teachers (e.g., pre-school), elementary/primary school teachers (Kindergarten/Preparatory to Grade 6), middle school teachers (e.g., Grades 6 to 8), and secondary/high school teachers (i.e., Grades 7 to 12). The terms early childhood, elementary, middle, and secondary school will be used throughout this review to ensure consistency in terminology. Tertiary education or vocational teachers were not included. Studies that combined an eligible teacher sample with another sample (e.g., students, parents) were included in the review if teachers comprised $>50 \%$ of the sample.

Types of programs. Eligible programs included any psychological program delivered to the identified population that aimed to impact their mental health, professional burnout, and/or wellbeing outcomes. These programs were defined as targeting thoughts, feelings, and/or responses to stressful situations. Examples include Cognitive-Behavioural Therapy, Mindfulness-Based Stress Reduction, and emotional-skills training. Programs that were not delivered to teachers or did not directly aim to impact their mental health, burnout, or wellbeing outcomes were excluded. To be included in the review, the psychological component/s of multi-component programs had to comprise $>75 \%$ of the program.

Types of control group. Studies were included in the review if they included any type of control (e.g., no-intervention or treatment as usual, waitlist control, attention control) or comparison group.

Types of outcomes. Studies were included if they reported outcomes for teachers that had a clear mental health, professional burnout, and/or wellbeing component. Mental health symptoms or diagnoses included anxiety, depression, stress, psychological distress, post-traumatic stress-disorder, secondary traumatic stress or vicarious trauma, somatisation, and sleep problems. Wellbeing outcomes included subjective wellbeing and quality of life, where subjective wellbeing refers to cognitive and/or additive appraisal of one's life (e.g., life satisfaction or work satisfaction). Secondary outcomes, including resilience, positive and negative affect, and fatigue, were included from studies that met all other inclusion criteria. All outcome measures needed to be valid and use reliable rating scales suitable for adults or teaching professionals.

Types of studies. Quantitative studies were included if they included any type of control or comparison group, namely RCTs, including cluster RCTs, and nRCTs. Studies were included if they were published in the English language in peer-reviewed journals. Studies without a control or comparison group, studies that were purely descriptive or qualitative, and protocol papers were excluded.

\section{Search Strategy}

Consistent with the PRISMA statement, we conducted a systematic search of three electronic databases: PsychINFO, MEDLINE, and EMBASE. We used a combination of keywords and Medical Subject Heading (MeSH) terms related to (a) teachers, (b) mental health, professional burnout, and wellbeing outcomes, and (c) interventions/programs. The search was conducted on $11^{\text {th }}$ of February 2020. See Appendix A for search strategy used for PsychINFO. The search was adapted to meet the requirements of each database. No limits were applied to the search. This search was re-run on the $13^{\text {th }}$ November 2020 and again on the $30^{\text {th }}$ November 2021 to identify recently published articles.

\section{Data Extraction and Management}

Study characteristics and outcomes were extracted by JRB, SS, and AR and entered into a Microsoft Excel spreadsheet. A smaller subset of extracted data (10\%) was checked independently by AW-S. There were no discrepancies. We extracted the following data when reported: author, year of publication, country of study, allocation level, control/comparison group, reimbursement, teacher type, universal (delivered to all teachers regardless of initial symptom levels) or indicated (delivered to teachers with elevated mental health symptom levels) sample, sample size, percent attrition from the program, mean age, percent female, program name and details (i.e., content, delivery method and setting, length, number of sessions, format, facilitator, home tasks, and program specificity to teachers), and outcomes. Program content was categorised based on the primary theoretical approach (e.g., mindfulness and/or relaxation, cognitive-behavioural skills, socio-emotional, relationship and/or interpersonal skills). Program specificity to teachers refers to whether the program was developed/adapted specifically for teachers or the school context or whether it was developed for another group/purpose and applied to teachers without adaptation. We also extracted length of follow-up for both the program and control groups when available. We extracted data for post-intervention (< 1 month), short-term (1-6 months inclusive), and/or long-term >6 months) follow-up. These categories were based on the time-periods most frequently reported by authors. Few studies reported intervention adherence or fidelity, school type and location, and so they are not considered further.

\section{Quality and Risk of Bias}

We used the Cochrane Collaboration Risk of Bias tool for RCTs (ROB-II, Sterne et al., 2019;) and for non-randomised intervention studies (ROBINS-II, Sterne et al., 2016) to assess the quality and risk of bias of studies included in the review. We selected domains based on relevance to psychology intervention trials.

ROB-II. We assessed studies in relation to: (1) allocation sequence and concealment, (2) deviations of intended intervention assignment, (3) missing outcome data, (4) measurement of the outcome, and (5) selective reporting of data. All papers were independently coded by two authors (JRB, SS, LM, BO, SL, and/or 
$\mathrm{AR})$, and the team resolved disagreements through discussion.

ROBINS-I. We assessed studies in relation to: a) bias due to confounding, b) bias in selection of participants into the study, c) bias due to deviations from intended interventions, d) bias due to missing data, e) bias in measurement of outcomes, and f) bias in selection of the reported result. Ratings were made independently by JRB and LM, and the authors resolved disagreements through discussion and consultation with AW-S.

\section{Meta-analytic Procedures And Analyses}

\section{Inclusion Criteria}

The meta-analyses involved more stringent criteria to enable stronger quantitative conclusions about efficacy of programs for teachers. For studies that combined an eligible teacher sample with another ineligible sample, they were only included in the meta-analyses if separate data was available for the eligible teaching subsample. Studies that used a comparison rather than a control group were included in the review for completeness, but not the metaanalyses.

\section{Data Extraction}

For studies meeting inclusion criteria, we extracted means, standard deviations, and sample size of completers at post-intervention, and short- and long-term follow-up. When means and standard deviations were not available, we extracted mean difference scores. In studies in which appropriate outcome data were not reported, JRB contacted the authors to obtain this information.

For studies that included data from total scale scores and component subscales, we only included relevant subscales (e.g., the Anxiety, Depression, and Somatisation Subscales of the Brief Stress Inventory were included, but not the Global Symptom Severity Index). For studies that included two measures of the same outcome domain (e.g., the Perceived Stress Scale and the Depression, Anxiety and Stress Scale - Stress Subscale), we included the most used measure across studies. For the Maslach Burnout Inventory, we used the emotional exhaustion subscale. For studies that included multiple wellbeing measures, we selected those that assessed general wellbeing over those that assessed satisfaction, and given the focus of our review on workplace, we selected work satisfaction measures over life satisfaction measures.

\section{Calculation of Effect Sizes}

We used Comprehensive Meta-Analysis (version 3.0, Biostat Inc.) to calculate individual study and pooled effect sizes. For each comparison between an intervention and control group, we calculated the standardised mean difference at post-intervention adjusted for small samples (Hedges' g; Hedges \& Olkin, 2014). This calculation involves subtracting the average score of the intervention group at post-intervention from the average score for the control group at post-intervention and dividing the result by the pooled standard deviation of the two groups (i.e., controlled effects). Effect sizes of $0.2,0.5$ and 0.8 refer to small, moderate, and large effect sizes, respectively (Cohen, 2013). We also calculated the $95 \%$ confidence interval around effect sizes. For studies that had multiple control groups, we divided the number of participants in the intervention group by the number of control groups such that each participant was only represented once in the meta-analyses. We used a random effects model because considerable heterogeneity among studies was expected. This model assumes that the true effect size varies from one study to the next, and therefore permits the generalisation of the corrected effect size estimate to the broader population (Borenstein, 2009).

We conducted meta-analyses separately for RCTs and nRCTs. For both types of trials, we calculated controlled post-intervention effect sizes for (i) depression, (ii) anxiety, (iii) stress, (iv) burnout, and (v) wellbeing. We also calculated controlled post-intervention effect sizes for somatisation in RCTs and for psychological distress in nRCTs. Short-term follow-up controlled effects were only calculated for nRCTs (anxiety, depression, stress, burnout, wellbeing). There were not enough studies to calculate effect sizes for the other primary and secondary outcome variables at each measurement point. The significance level for these analyses was set at $p<.008(.05 / 6)$ following a Bonferroni correction.

\section{Heterogeneity}

We calculated the $R$ statistic to test the heterogeneity of effect sizes at post-intervention. $I^{2}$ values are commonly expressed as percentages, whereby $25 \%$, $50 \%$, and $75 \%$ correspond to low, medium, and high levels of heterogeneity, respectively (Higgins \& Thompson, 2002). The $95 \%$ confidence interval limits were also calculated to estimate dispersion in the observed effect sizes.

\section{Additional Analyses}

Additional analyses were planned, however, there was an inadequate number of comparisons to perform sub-group analyses, meta-regression, or publication bias analyses for each of the primary outcomes. Guidelines suggest that at least 10 studies are needed in a meta-analysis to adequately power tests of moderation and funnel plot asymmetry (Higgins, updated February 2021; Tanner-Smith \& Grant, 2018).

\section{Descriptive Results}

\section{Selection of Studies}

See Figure 1 for the PRISMA diagram illustrating the study selection process. A total of 19,592 articles were identified, from which 3816 duplicates were removed. Titles and abstracts of 15,776 articles were screened for eligibility. JRB screened articles from the original search. JB, SS, and AR screened articles from the updated searches. 15,573 articles were deemed irrelevant and therefore excluded. JRB, SS, and AR then independently screened the full text articles 
of the remaining 203 records. Of these records, 120 were excluded because they did not meet the inclusion criteria. Any disagreements were resolved through discussion and consultation with AW-S. Screening resulted in 83 articles (46 RCTs, 37 nRCTs) being included in the current review. One article (Jennings et al., 2019) reported follow-up data of an RCT reported separately (Jennings et al., 2017), leaving 82 original studies included in the review. Of these articles, 39 were included in the meta-analyses (19 RCTs, 20 nRCTs).

\section{$<$ INSERT FIGURE 1>}

\section{Study Characteristics}

See Tables 1 and 2 for characteristics of included RCTs and nRCTs, respectively. The 82 unique studies included in the current review had a total of 8325 participants. Sample sizes were generally small, with a median of 62.5 participants (range: 14 to 961 ). For primary mental health outcomes, 30 ( $36.69 \%$ ) studies examined anxiety, 23 (28.05\%) examined depression, 47 (57.32\%) examined stress, four (4.88\%) examined psychological distress, one (1.22\%) examined trauma, seven (8,54\%) examined sleep, three (3.66\%) examined somatisation, 37 (45.12\%) examined burnout, and 24 (29.27\%) examined wellbeing including work/life satisfaction. For secondary outcomes, five (6.1\%) studies examined resilience, 16 (19.51\%) examined positive/negative affect, and three (3.66\%) examined fatigue.

\section{Control Group}

Most studies included a control group ( $n=71,86.59 \%)$, with 11 evaluating the intervention against a comparison group such as another individual psychological intervention or a classroom-management style intervention (13.41\%). Most studies used a passive control group ( $n=62,85.92 \%)$, including a waitlist control $(n=34,53.97 \%)$ or a no-intervention control $(n=29,46.03 \%)$. No-intervention control groups were those that did not received the formalised intervention at any point during the study. Three studies (4.23\%) used an active control, and one study (1.41\%) used a combination of passive and active control groups. Five (7.04\%) studies did not specify the type of control group.

\section{Population Characteristics}

Most studies were conducted in the United States of America or Canada $(n=26,31.71 \%)$, followed by Europe $(n=19,23.17)$ and Asia $(n=19,23.17 \%)$. Most studies exclusively recruited school teachers that had a primary teaching role $(n=61,74.39 \%)$, although 19 (23.17\%) studies included other school professionals (e.g., counsellors, principals, administration staff, assistants) and 2 studies $(2.44 \%)$ did not specify the type of teaching sample. There were a variety of teaching levels investigated. Just under one third $(n=24,29.27 \%)$ of the studies included a combination of teaching levels (e.g., pre-school, elementary, and secondary), while 19 (23.17\%) focused on secondary levels, 14 (17.07\%) focused on elementary levels, and two (2.44\%) focused on middle school levels. Fewer studies focused on pre-service $(n=8,9.76 \%)$, special education $(n=6,7.32 \%)$, and early childhood $(n=2,2.44 \%)$, and seven $(8.54 \%)$ studies did not provide any information about teaching level. Most studies delivered programs universally $(n=71,86.59 \%)$; 11 (13.41\%) studies delivered programs to indicated samples. The samples were predominantly female (78.66\%, range=32.26\%-100\%), with a mean age of 39.75 years. See Tables 1 and 2 for additional details about the population.

\section{Randomisation}

The largest proportion of studies randomised teachers at the individual level ( $n=60,73.17 \%$ ), followed by randomisation at the school level ( $n=15$ studies, $18.29 \%$ ). Four studies randomised at the classroom level (4.88\%), two randomised at the university/college level (i.e., for pre-service school teachers; $2.44 \%$ ), and one study did not report level of randomisation (1.22\%).

\section{Program Characteristics}

Program content. Most studies examined a mindfulness and or/relaxation-based program ( $n=31,37.8 \%$ ), followed by cognitive-behavioural skills ( $n=13$, $15.85 \%)$, stress management skills $(n=13,15.85 \%)$, and then socio-emotional, relationship and/or interpersonal skills ( $n=8,9.76 \%)$. Fewer studies included rational emotive behaviour therapy programs $(n=5,6.1 \%)$ or acceptance and commitment therapy programs $(n=2,2.44 \%)$. A group of studies $(n=10,12.2 \%)$ used strategies that did not fall into these categories. This group of studies combined many different theoretical approaches to psychological therapy (e.g., acceptance and commitment, cognitive-behavioural, visualisation, and relaxation skills), or focused on gratitude skills, work environment strategies, sleep education, or transpersonal psychology. Most programs were context-specific, meaning that they were developed/adapted for teachers ( $n=62,75.61 \%)$. These programs typically included strategies that addressed stressors and experiences characteristic of the teaching role and workplace environment, as well as strategies that addressed teacher mental health issues. Other programs were context-general, applied to teachers without any adaptation to their role or workplace $(n=18,2.44 \%)$. Two $(2.44 \%)$ studies did not provide enough information to categorise. The majority $(n=70,85.37 \%)$ of the studies reported on home task requirements of the programs. Home tasks were varied in terms of length and duration, ranging from $30-40$ minutes of formal mindfulness practice each day for 5-weeks (Vesely et al., 2014) to conducting progressive muscle relaxation each day for 8 minutes throughout the program (Shimazu et al., 2003).

Format and delivery. Most programs were conducted face-to-face $(n=73,90.12 \%)$, were delivered exclusively in group format ( $n=64,80 \%)$, and were either school-based $(n=28,34.16 \%)$ or school-supported $(n=17,20.73 \%)$. School-based refers to a program that is endorsed by the school and delivered to teachers during school hours, or before/after school, on school premises. School-supported refers to a program that is endorsed by the school, but does not require additional school resourcing (e.g., time/funding). Most programs were delivered over 1-12 weeks ( $n=56,68.29 \%)$, comprised 1-8 sessions ( $n=51,62.2 \%)$ with each session lasting between $1-4$ hours ( $n=48,58.54 \%$ ). Over half of studies identified the intervention facilitator $(n=60,73.17 \%)$. Of these studies, 53 ( $88.33 \%)$ used a facilitator that was external to schools, including accredited or certified trainers (e.g., qualified mindfulness practitioner teachers), clinical psychologists, and researchers. Only $3(5 \%)$ studies reported using a facilitator that was internal to the school context, such as a teacher or nurse. Four 
(6.67\%) studies did not require a facilitator because the programs were self-guided or delivered online. See Tables 1 and 2 for additional details about format and delivery.

\section{Reimbursement}

Most studies $(n=64,78.05 \%)$ reported whether teachers received reimbursement for their participation, of which 47 (57.32\%) did not provide any reimbursement. For the studies that did report providing reimbursement $(n=17,20.73 \%)$, there was considerable variation ranging from professional development points or course credits, reduced pricing for the program, money, and a chance to earn gift certificates.

\section{Outcomes}

A wide range of measures was used to assess primary outcomes, with a total number of 65 across the studies included in the review (not including individual subscales). See Tables 1 and 2. Stress and burnout were the most consistently measured outcomes, with 23 (48.94\%) studies using the Perceived Stress Scale and 29 (78.38\%) studies using the Maslach Burnout Inventory. The State Trait Anxiety Inventory - State Subscale ( $n=10,33.33 \%)$ was the most used measure for anxiety, and the Depression, Anxiety, Stress Scales - Depression Subscale ( $n=8,34.78 \%)$ was the most used measure for depression. There was no clear consistency in the measures used to assess psychological distress, somatisation, sleep problems, or wellbeing.

\section{Length of Follow-Up}

For the first measurement point, $70(85.37 \%)$ studies measured outcomes within one-month of finishing the intervention, $9(10.98 \%)$ studies measured outcomes 1-6 months after post-test, and two (2.44\%) studies measured outcomes more than 6 months after post-test. Only 26 (31.71\%) studies reported relevant follow-up measures for both the control and program groups. Of these studies, 24 (92.31\%) were assessed 1-6 months after post-test and 2 (7.69\%) were assessed more than 6 months after post-test. One study included a follow-up measure but did not specify when the measurement took place.

\section{Attrition}

Over half of the studies $(n=54,65.85 \%)$ reported percentage attrition from the program. Average attrition from the program group was $13.5 \%$, ranging from $0 \%$ to $66.67 \%$.

$<$ INSERT TABLE $1>$

$<$ INSERT TABLE 2>

\section{Risk of Bias}

ROB-II. As seen in Table 3, half ( $n=23$ ) of the RCTs were assessed to have some concerns and the other half ( $n=23$ ) were assessed to have high risk of bias. Most studies were assessed to have some concerns due to participants being aware of the assigned intervention $(n=44 ; 95.65 \%)$ or due to an absence of a pre-specified analysis plan ( $n=42 ; 91.3 \%$ ). High risk of bias was most typical in the missing outcome domain, with $60.87 \%$ ( $n=28)$ of the studies not reporting enough information about dropout or (Higgins, updated February 2021) not accounting for dropout. Approximately $69.87 \%$ of studies ( $n=32$ ) did not report enough information to ascertain whether intervention allocations could have been foreseen prior to or during enrolment.

$<$ INSERT TABLE 3>

ROBINS-I. As seen in Table 4, 34 (83.78\%) of the nRCTs were assessed to have serious risk of bias and the remaining 3 (8.12\%) were assessed to have critical risk of bias. This result was primarily due to the outcome domain. All but one of the studies $(n=36,89.19 \%)$ were assessed to have serious risk of bias because the measurement tools were self-report and the participants were likely aware of the intervention received. In addition, 18 studies (48.64\%) had serious or critical risk of bias in the reporting domain because they lacked a clear analysis plan, and 19 studies (51.35\%) had serious or critical risk of bias in the confounding domain because they lacked experimental and statistical control of extraneous variables. Nine (24.32\%) of studies did not report enough information about missing data to make a judgment about risk.

$<$ INSERT TABLE 4>

\section{Meta-analytic Results}

Meta-analyses using random effects models were conducted for RCTs and nRCTs separately to compare the intervention and control groups on the outcomes at post-intervention and follow-up (i.e., controlled effects). Outcomes with enough studies to be meta-analysed included anxiety, depression, stress, psychological distress, somatisation, burnout, and wellbeing. The significance threshold was set at $p<.008$. See Figures 3-14 in Appendix B for forest plots.

\section{Randomised Controlled Trials}

Controlled effects at post-intervention were significant and of a large size for stress ( $g=1.16, k=8, \mathrm{Cl}_{95}=0.43-1.88$, $\left.p=.002\right)$, and of a moderate size for burnout $\left(g=0.58, k=9, \mathrm{Cl}_{95}=0.26-0.90, p<.001\right)[1]$ and wellbeing $\left(g=0.68, k=4, \mathrm{Cl}_{95}=0.27-1.09, p=.001\right)$. Post-intervention effects were not significant at the conservative threshold for anxiety $\left(g=0.51, k=2, \mathrm{Cl}_{95}=0.06-0.96, p=.03\right)$, depression $\left(g=0.25, k=3, \mathrm{Cl}_{95}=0.00-0.50, p=.05\right)$, and psychological distress $\left(g=3.84, k=2, \mathrm{Cl}_{95}=-2.19\right.$ $9.86, p=.21)$. The short-term follow-up intervention effect sizes were large and significant for stress $\left(g=1.84, k=5, \mathrm{Cl}_{95}=0.61-3.07, p=.003\right)$, but non-significant for anxiety $\left(g=2.64, k=2, \mathrm{Cl}_{95}=-1.82-7.10, p=.25\right)$ and burnout $\left(g=0.84, k=4, \mathrm{Cl}_{95}=0.17-0.15, p=.02\right)$. 
Heterogeneity. Based on $7^{2}$ statistics sizes (see Table 5), there was high heterogeneity in the controlled effects at post-intervention for stress, psychological distress, and burnout. There was low to medium heterogeneity for depression, anxiety, and wellbeing. The heterogeneity estimates for stress and burnout were estimated with some precision, whereas the other estimates were not. This imprecision likely reflects small sample sizes (von Hippel, 2015).

$<$ INSERT TABLE 5>

\section{Non-Randomised Controlled Trials}

Controlled effects at post-intervention were significant and of a small to moderate size for anxiety $\left(g=0.42, k=9, \mathrm{Cl}_{95}=0.17-0.67, p=.001\right)$, depression $(g=0.36$, $\left.k=6, \mathrm{Cl}_{95}=0.09-0.62, p=.008\right)$, stress $\left(g=0.62, k=9, \mathrm{Cl}_{95}=0.39-0.86, p<.001\right)$, and wellbeing $\left(g=0.44, k=7, \mathrm{Cl}_{95}=0.24-0.65, p<.001\right)$. Effects were non-significant for somatisation ( $g=0.75, k=2, \mathrm{Cl}_{95}=0.61-2.11, p=.28$ ) and burnout ( $g=0.28, k=4, \mathrm{Cl}_{95}=-0.02-0.58, p=.07$ ). Controlled effects at short-term follow-up were nonsignificant for anxiety $\left(g=0.33, k=3, \mathrm{Cl}_{95}=0.08-0.59, p=.011\right)$, depression $\left(g=0.09, k=2, \mathrm{Cl}_{95}=-0.20-0.38, p=.53\right), \operatorname{stress}(g=1.13, k=3, \mathrm{Cl} 95=-0.28-2.54, p=.12)$, burnout $\left(g=0.14, k=2, \mathrm{Cl}_{95}=-0.28-0.57, p=.51\right)$, and wellbeing $\left(g=0.15, k=3, \mathrm{Cl}_{95}=-0.09-0.39, p=.23\right)$

Heterogeneity. Based on $7^{2}$ statistics (see Table 6), there was moderate to high heterogeneity in the controlled effects at post-intervention for depression, anxiety, stress, wellbeing, and somatisation. The wide confidence intervals indicate that these estimates are imprecise. The heterogeneity estimates for burnout and somatisation may not be reliable given the few comparisons contributing to the effect size (von Hippel, 2015).

\section{$<$ INSERT TABLE 6>}

[1] Based on a series of sensitivity analyses, one study (Ugwoke et al. 2018) was treated as an outlier and removed for burnout. Removing this study almost halved the estimated mean effect size (i.e., from $g=1.05$ to $g=0.58$ ).

\section{Discussion}

We systematically reviewed the existing literature on psychological programs for the mental health, burnout, and wellbeing of school classroom teachers. We identified 82 unique studies with a total of 8325 participants for the review (including 45 RCTs and 37 nRCTs). Consistent with existing literature, there was wide variability in the programs in terms of theoretical approach, structure, and format. We also calculated overall program effects on anxiety, depression, stress, psychological distress, somatisation, burnout, and wellbeing. We found that the psychological programs evaluated by these studies have positive effects for a range of mental health outcomes, as well as burnout and wellbeing, relative to control groups.

The meta-analyses showed that teacher programs are superior to control groups on most outcomes at the immediate post-test, with some effects sustained over the short-term (1-6 months). The size of the immediate effects varied. In RCTs, evaluated programs had significant large effects on stress ( $g=1.16)$, and moderate effects on burnout $(g=0.58)$ and wellbeing $(g=0.68)$ compared to controls. In nRCTs, programs had significant moderate effects on stress ( $g=0.62)$, and small to moderate effects on anxiety $(g=0.42)$, depression $(g=0.36)$, and wellbeing $(g=0.44)$ compared to controls. The effect sizes for stress increased in size for both types of trials over the short-term compared to controls ( $g s=1.13-1.84$ ), although the effect was only significant for RCTs. Few studies evaluated sustained effects over time. Follow-up measurements are necessary to evaluate whether effects persist or deteriorate over time. Overall, these findings are generally consistent with other meta-analyses that investigated the controlled effects of different programs on teacher mental health, burnout, or wellbeing outcomes (lancu et al., 2018; Klingbeil \& Renshaw, 2018; Oliveira et al., 2021; Zarate et al., 2019).

Despite the promising findings from our meta-analyses, there was considerable heterogeneity in the included studies. Confidence intervals either could not be estimated due to small samples or indicated that heterogeneity estimates were imprecise. The exception to this pattern was burnout and stress outcomes in RCTs, for which heterogeneity was high and estimated with precision. In this case, high heterogeneity most likely captures the cross-disciplinary and emerging nature of the field. The implication is that researchers are using different programs, research designs, methods, and analysis techniques to explore effects on teacher outcomes. Support for this explanation comes from our review findings. Of note, there was a lack of consistency in how mental health, burnout, and wellbeing outcomes were measured, and the types of programs being evaluated. Programs were eclectic in terms of duration and frequency of sessions (i.e., intensity), delivery setting and level of school involvement, learned strategies, and the theory underpinning the treatment model (e.g., cognitive-behavioural principles, mindfulness principles, demands-resources model of coping, transpersonal theory etc). This finding converges with other descriptive systematic reviews and meta-analyses investigating teacher mental health programs (e.g., Dreer \& Gouasé, 2021; Klingbeil \& Renshaw, 2018; von der Embse et al., 2019).

Across the breadth and variety of psychological programs included in this review, one consistent similarity emerged. Most programs required significant time, effort, and resources for the teachers to complete. For example, programs were typically delivered face-to-face, in groups in dedicated spaces, and required trained or accredited facilitators who were external to the school. Sessions were also demanding. Most programs included 1-8 sessions that lasted between 14 hours each, delivered over 1-12 weeks, in teachers' own time. These programs typically followed structured or manualised psychological intervention protocols. For example, mindfulness and/or relaxation-based programs were the most common (37.8\%) followed by cognitive-behavioural skills (15.85\%) and stress management skills (15.85\%). These programs require a significant time commitment for a workforce that is renowned for being time-poor and struggling to cope with ever-changing job demands (Thomson, 2020). Time is often identified by teachers as a major barrier to engaging in and completing programs (Fang et al., 2021). Study attrition rates support this as a barrier. Our review showed that attrition rates reached as high as $66.67 \%$ in the program groups, with an overall mean of $13.5 \%$. It may be the case the attrition was higher in more demanding programs. We were unable to formally test this hypothesis due to small sample sizes in our meta-analyses, and review findings may be skewed because over $30 \%$ of studies did not report attrition.

Programs do not have to be time- or resource-intensive to be effective. For example, providing programs online is one way to reduce demands. This delivery method can be fully automatic, meaning that highly trained experts are not needed to facilitate sessions, and can be asynchronous, meaning that teachers 
can complete modules in their own time. For example, one study evaluated an online stress management skills program in pre-service, elementary, and secondary school teachers (Ansley et al., 2021). The program was self-paced and consisted of eight 30-minute modules, with the recommendation of completing two modules per week for four weeks. Most teachers (92.8\%) completed the program, defined by the study authors as completing $75 \%$ of the modules. The program (versus control) was associated with decreased emotional exhaustion, a core feature of burnout. Another study evaluated internetbased problem-solving training, consisting of one self-guided lesson per week for five weeks, in a teaching sample with elevated depression levels (Ebert et al., 2014). The training (versus control) reduced depressive symptoms, as well as stress and worry, at post-test, three-month follow-up, and six-month follow-up. Over half $(60 \%)$ of teachers completed the program. These completion rates are reasonable given the low intensity of the programs and compare well to rates in other studies evaluating internet-based stress management programs in employee samples (Zarski et al., 2016). Asynchronous online programs may overcome logistical issues in implementation (e.g., organising times, dates, and locations for sessions), prevent premature discontinuation, and be more feasible to roll-out at scale.

Most of the studies included in the review did not measure program fidelity and program adherence. Fidelity refers to the extent to which a program is delivered as intended (Carroll et al., 2007; Schoenwald et al., 2011) and adherence refers to the extent to which participants completed the program requirements (e.g., all sessions/modules). Fidelity and adherence are important in the translation of research to practice when implementing programs in the real-world. They are key indicators of whether a program is appropriate/acceptable for the intended audience and context, whether there are enough resources to support delivery, and whether it is being used (Carroll et al., 2007). This information is essential to guide effective decisions about which programs to implement, to whom, and when (Peters et al., 2013). Similar to other work in this field (Werner-Seidler et al., 2017), our position is that taking steps to ensure program fidelity and adherence must be a priority in future research. Exploring the extent to which adherence influences outcomes has not yet been investigated in teacher mental health research.

\section{Methodological Quality}

The quality of studies across both RCTs and nRCTs was problematic. Awareness of the assigned intervention, use of self-report measures, absence of a prespecific analysis plan, and lack of information about missing data and drop out were assessed to be key contributors to bias. Masking intervention assignment in psychological research is difficult because of the inherent nature of psychological interventions; they generally involve a psychoeducational component and require participants to actively learn and engage in new skills. Similarly, using self-report measures in psychological research is the standard approach to assess subjective internal states. Given their ubiquity in the field, awareness and response biases may be less problematic than others identified in our review. Ensuring that methods are transparent and replicable (e.g., by registering protocol and data analysis plans using open science principles) and accurately represent the data (e.g., by using intention to treat analyses and accounting for missing data) will go part way to address bias in analyses and reporting.

Almost half (44.58\%) of the studies in the review were nRCTs. Whilst these trials do provide useful information about effectiveness, it is conceptually difficult reach a level of quality that is comparable to an RCT. We classified all nRCTs as having either serious or critical risk of bias. NRCTs are often an initial step in the research process to gauge uptake and response to programs because they are easier to implement that RCTs in real-world contexts. Randomising working teachers, or schools, to different interventions can be difficult, particularly when they are interested in receiving a potentially helpful program. However, our meta-analyses showed that effect sizes were generally larger in RCTs than in nRCTs. RCTs will be an important way forward as the field matures.

\section{Limitations}

The results of this systematic review and meta-analyses need to be interpreted in the context of some limitations. Due to practical reasons, we only included peer-reviewed studies that were published in English and we did not include grey literature or unpublished studies. Another limitation was the small number of studies included in the meta-analyses. There were not enough effect sizes to do more comprehensive meta-analyses, explore moderators, or evaluate publication bias. Further, our analyses were likely underpowered to detect small-to-moderate between-group effect sizes for some outcome measure with small sample sizes. Updated meta-analyses are needed once more studies become available in the mental health, burnout, and wellbeing domains.

\section{Future Research}

Our systematic review and meta-analyses identified several areas for future research. Increased consistency in measurement is needed to clarify how programs affect specific mental health, burnout, and wellbeing outcomes in the teaching workforce and enable comparison across studies. Increased focus is also needed on less studied, but equally important, outcomes such as trauma, sleep, and resilience. Future research should take a systematic approach to measurement, not only using standardised measures with sound psychometric properties, but also those that are validated with teachers and the school context. More comprehensive evaluation of follow-up periods to gauge the trajectory of effects over time once a program has finished is also necessary to further quantify effectiveness. Overall, there is a clear need for rigorous methodology in study design to reduce risk of bias and increase validity and reliability of findings.

Translation from research trials to the real-world is a critical factor to consider when designing and rolling-out programs. Even though the programs identified in our review and meta-analyses are generally effective, their translational potential is unclear. This is particularly the case given how demanding and resource heavy the available programs currently are. Such characteristics are problematic given the high program attrition identified in our review. Insights from codesign research have potential to transform the nature of programs being developed and the studies being designed to evaluate them. Co-design involves relevant stakeholders in the conceptualisation and/or development of programs (Sanders \& Stappers, 2008). Most programs identified in our review were developed or adapted for teachers (75.61\%). Although we did not specifically extract and analyse data on co-design, we did not identify any papers that reported co-design principles. Involving teachers, as well as school leadership and representatives from relevant governing bodies, is important to understand 
what they want and how a program would fit within the school context. This process would likely increase the feasibility of implementation, perceived acceptability from those intended to use and benefit from the program and, in turn, the uptake and effectiveness of the program (Steen et al., 2011).

\section{Conclusions}

Our systematic review and meta-analyses identified, described, and evaluated psychological programs targeting the mental health, burnout, or wellbeing of school teachers. We found that the programs currently available can reduce stress, depression, anxiety, and burnout, and increase wellbeing relative to controls. However, there is a need for future studies to prioritise methodological rigor to produce valid results that can be replicated. Most programs currently available require significant time, effort, and resources to deliver and complete. Teachers are time poor, and these programs may not translate well outside of research trials to real-world contexts. Incorporating principles from co-design and implementation research, as well as considering novel ways of delivering programs that reduce demands on teachers (e.g., online programs delivered asynchronously) are necessary to develop programs that work, but that are also used as intended. Against the backdrop of worsening outcomes for teachers due to everchanging roles and responsibilities, as well as unpredictable community events (e.g., COVID-19, other natural disasters), now is the time to develop and evaluate programs that address teacher mental health, burnout, and wellbeing.

\section{Declarations}

\section{Funding:}

This study was supported by the Black Dog Institute, a NHMRC Emerging Leadership Fellowship awarded to AW-S (GNT1197074), and a MRFF Career Development Fellowship awarded to JN. The funders had no role in the study design, collection, analysis, or interpretation of the data, writing the manuscript, or the decision to submit the paper for publication.

\section{Competing Interests:}

None to declare.

\section{Ethics Approval and Consent to Participate:}

Not applicable.

Availability of Data and Material:

Not applicable.

\section{Author Contributions:}

JRB, AW-S, and BO contributed to the study conception and design. JRB, SS, and AR conducted screening and data extraction. JRB summarised the descriptive data for the review and conducted the meta-analyses. JN provided guidance on the quantitative data analyses. JRB, SS, AR, LM, SL, and BO conducted the risk of bias assessments. The first draft of the manuscript was written by JRB. All authors commented on previous versions of the manuscript. All authors read and approved the final manuscript.

\section{References}

1. *Denotes articles included in the review

2. Alliance for Excellent Education (2014). On the path to equity: Improving the effectiveness of beginning teachers (issue brief). Retrieved from http://all4ed.Org/reports-factsheets/path-to-equity/

3. *Ancona, M. R., \& Mendelson, T. (2014). Feasibility and preliminary outcomes of a yoga and mindfulness intervention for school teachers. Advances in School Mental Health Promotion, 7(3), 156-170. https://doi.org/10.1080/1754730x.2014.920135

4. *Ansley, B. M., et al. (2021). The impact of an online stress intervention on burnout and teacher efficacy. Teaching and Teacher Education, $98,103251$. https://doi.org/10.1016/j.tate.2020.103251

5. *Au, D. W., et al. (2016). Psychosomatic and physical responses to a multi-component stress management program among teaching professionals: A randomized study of cognitive behavioral intervention (cb) with complementary and alternative medicine (cam) approach. Behaviour Research and Therapy, 80, 10-16. https://doi.org/10.1016/j.brat.2016.02.004

6. Beames, J. R., et al. (2021). School teachers: The forgotten frontline workers of covid-19. Australasian Psychiatry, 10398562211006145. https://doi.org/10.1177/10398562211006145

7. *Benn, R., et al. (2012). Mindfulness training effects for parents and educators of children with special needs. Developmental Psychology, 48(5), 14761487. https://doi.org/10.1037/a0027537

8. *Berger, R., et al. (2016). Reducing primary and secondary traumatic stress symptoms among educators by training them to deliver a resiliency program (erase-stress) following the christchurch earthquake in new zealand. American Journal of Orthopsychiatry, 86(2), 236-251.

https://doi.org/10.1037/ort0000153

9. *Berkovich-Ohana, A., et al. (2020). Effects of a mindfulness intervention among arab teachers are mediated by decentering: A pilot study. Frontiers in Psychology, 11, 542986. https://doi.org/10.3389/fpsyg.2020.542986

Page $9 / 29$ 
10. *Bertoch, M. R., et al. (2014). Reducing teacher stress. The Journal of Experimental Education, 57(2), 117-128. https://doi.org/10.1080/00220973.1989.10806500

11. *Beshai, S., et al. (2015). A non-randomised feasibility trial assessing the efficacy of a mindfulness-based intervention for teachers to reduce stress and improve well-being. Mindfulness, 7(1), 198-208. https://doi.org/10.1007/s12671-015-0436-1

12. *Biglan, A., et al. (2013). The value of workshops on psychological flexibility for early childhood special education staff. Topics in Early Childhood Special Education, 32(4), 196-210. https://doi.org/10.1177/0271121411425191

13. *Carroll, A., et al. (2021). Improving emotion regulation, well-being, and neuro-cognitive functioning in teachers: A matched controlled study comparing the mindfulness-based stress reduction and health enhancement programs. Mindfulness. https://doi.org/10.1007/s12671-021-01777-4

14. *Castillo-Gualda, R., et al. (2017). Preliminary findings from ruler approach in spanish teachers' emotional intelligence and work engagement. Electronic Journal of Research in Educational Psychology, 15(3), 641-664. https://doi.org/10.14204/ejrep.43.17068

15. *Castillo-Gualda, R., et al. (2019). The role of emotional regulation ability, personality, and burnout among spanish teachers. International Journal of Stress Management, 26(2), 146-158. https://doi.org/10.1037/str0000098

16. *Cecil, M. A., \& Forman, S. G. (1990). Effects of stress inoculation training and coworker support groups on teachers' stress. Journal of School Psychology, 28(2), 105-118. https://doi.org/http://dx.doi.org/10.1016/0022-4405\%2890\%2990002-0

17. *Chan, D. W. (2013). Counting blessings versus misfortunes: Positive interventions and subjective well-being of chinese school teachers in hong kong. Educational Psychology, 33(4), 504-519. https://doi.org/10.1080/01443410.2013.785046

18. ${ }^{*}$ Cheng, X., et al. (2021). The effect of mindfulness-based programs on psychological distress and burnout in kindergarten teachers: A pilot study. Early Childhood Education Journal. https://doi.org/10.1007/s10643-021-01254-6

19. *Cicotto, G., et al. (2014). Psychosocial training: A case of self-efficacy improvement in an italian school. Journal of Change Management, 14(4), 475499. https://doi.org/10.1080/14697017.2014.978536

20. Cohen, J. (2013). Statistical power analysis for the behavioral sciences. Academic press

21. *Cook, C. R., et al. (2017). Promoting secondary teachers' well-being and intentions to implement evidence-based practices: Randomized evaluation of the achiever resilience curriculum. Psychology in the Schools, 54(1), 13-28. https://doi.org/10.1002/pits.21980

22. *Cooley, E., \& Yovanoff, P. (1996). Supporting professionals-at-risk: Evaluating interventions to reduce burnout and improve retention of special educators. Exceptional Children, 62(4), 336-355. https://doi.org/10.1177/001440299606200404

23. *Dahal, P. P., \& Pradhan, B. (2018). Effect of 1-month cyclic meditation on perceived stress, general health status, and cardiovascular parameters in school teachers. Advances in Mind-Body Medicine, 32(2), 4-9

24. *de Carvalho, J. S., et al. (2021). Effects of a mindfulness-based intervention for teachers: A study on teacher and student outcomes. Mindfulness, 12(7), 1-14. https://doi.org/10.1007/s12671-021-01635-3

25. *de Souza, J. C., et al. (2016). Effect of a sleep education program on sleep knowledge and habits in elementary and high school teachers. Estudos de Psicologia, 21(4), 369-380

26. *Dicke, T., et al. (2015). Reducing reality shock: The effects of classroom management skills training on beginning teachers. Teaching and Teacher Education, 48, 1-12. https://doi.org/10.1016/j.tate.2015.01.013

27. *Dike, I. C., et al. (2021). Yoga complemented cognitive behavioral therapy on job burnout among teachers of children with autism spectrum disorders. Medicine, 100(22), e25801. https://doi.org/10.1097/MD.0000000000025801

28. Dreer, B., \& Gouasé, N. (2021). Interventions fostering well-being of schoolteachers: A review of research. Oxford Review of Education, 1-19. https://doi.org/10.1080/03054985.2021.2002290

29. *Dyer, N. L., et al. (2020). A pragmatic controlled trial of a brief yoga and mindfulness-based program for psychological and occupational health in education professionals. Complementary Therapies in Medicine, 52(102470), 102470. https://doi.org/10.1016/j.ctim.2020.102470

30. *Ebert, D. D., et al. (2014). Efficacy of an internet-based problem-solving training for teachers: Results of a randomized controlled trial. Scandinavian Journal of Work, Environment \& Health, 40(6), 582-596. https://doi.org/10.5271/sjweh.3449

31. *Fabbro, A., et al. (2020). Effects of mindfulness training on school teachers' self-reported personality traits as well as stress and burnout levels. Perceptual and Motor Skills, 127(3), 515-532. https://doi.org/10.1177/0031512520908708

32. Fang, G., et al. (2021). Secondary school teachers' professional development in australia and shanghai: Needs, support, and barriers. SAGE Open, 11(3), https://doi.org/10.1177/21582440211026951

33. *Figl-Hertlein, A., et al. (2014). A physiotherapy-directed occupational health programme for austrian school teachers: A cluster randomised pilot study. Physiotherapy, 100(1), 20-26. https://doi.org/10.1016/j.physio.2013.03.003

34. *Flook, L., et al. (2013). Mindfulness for teachers: A pilot study to assess effects on stress, burnout and teaching efficacy. Mind Brain and Education, 7(3), 182-195. https://doi.org/10.1111/mbe. 12026

35. *Forman, S. G. (1982). Stress management for teachers: A cognitive-behavioral program. Journal of School Psychology, 20(3), $180-187$. https://doi.org/http://dx.doi.org/10.1016/0022-4405\%2882\%2990047-4

36. *Franco, C., et al. (2010). Reducing teachers' psychological distress through a mindfulness training program. The Spanish Journal of Psychology, 13(2), 655-666. https://doi.org/10.1017/s1138741600002328

37. *Frank, J. L., et al. (2013). The effectiveness of mindfulness-based stress reduction on educator stress and well-being: Results from a pilot study. Mindfulness, 6(2), 208-216. https://doi.org/10.1007/s12671-013-0246-2

Page $10 / 29$ 
38. *Friedman, G. H., et al. (1983). The effectiveness of self-directed and lecture/discussion stress management approaches and the locus of control of teachers. American Educational Research Journal, 20(4), 563-580. https://doi.org/10.2307/1162814

39. García-Carmona, M., et al. (2019). Burnout syndrome in secondary school teachers: A systematic review and meta-analysis. Social Psychology of Education, 22(1), 189-208. https://doi.org/10.1007/s11218-018-9471-9

40. *Goetz, K., et al. (2013). Primary prevention programme for burnout-endangered teachers: Follow-up effectiveness of a combined group and individual intervention of afa breathing therapy. Evidence-Based Complementary \& Alternative Medicine, 2013, 798260. https://doi.org/10.1155/2013/798260

41. *Gouda, S., et al. (2016). Students and teachers benefit from mindfulness-based stress reduction in a school-embedded pilot study. Frontiers in Psychology, 7, 590. https://doi.org/10.3389/fpsyg.2016.00590

42. *Grant, A. M., et al. (2010). Developmental coaching for high school teachers: Executive coaching goes to school. Consulting Psychology Journal: Practice and Research, 62(3), 151-168. https://doi.org/10.1037/a0019212

43. Gu, Q., \& Day, C. (2013). Challenges to teacher resilience: Conditions count. British educational research journal, 39(1), 22-44

44. *Hall, E., et al. (1997). The effects of human relations training on reported teacher stress, pupil control ideology and locus of control. British Journal of Educational Psychology, 67(4), 483-496. https://doi.org/10.1111/j.2044-8279.1997.tb01260.x

45. *Harris, A. R., et al. (2015). Promoting stress management and wellbeing in educators: Feasibility and efficacy of a school-based yoga and mindfulness intervention. Mindfulness, 7(1), 143-154. https://doi.org/10.1007/s12671-015-0451-2

46. Hedges, L. V., \& Olkin, I. (2014). Statistical methods for meta-analysis. Academic press

47. Higgins, J. P. T., Chandler, T. J., Cumpston, J., Li, M., Page, T., \& Welch, M. J. VA (Eds.). (February 2021).. ((updated). Cochrane handbook for systematic reviews of interventions version 6.2, Cochrane, 2021. Available from

48. Higgins, J. P., \& Thompson, S. G. (2002). Quantifying heterogeneity in a meta-analysis. Stat Med, 21(11), 1539-1558. https://doi.org/10.1002/sim.1186

49. Howard, S., \& Johnson, B. (2004). Resilient teachers: Resisting stress and burnout. Social Psychology of Education, 7(4), 399-420

50. *Hwang, Y. S., et al. (2019). Mindfulness-based intervention for educators: Effects of a school-based cluster randomized controlled study. Mindfulness, 10(7), 1417-1436. https://doi.org/10.1007/s12671-019-01147-1

51. lancu, A. E., et al. (2018). The effectiveness of interventions aimed at reducing teacher burnout: A meta-analysis. Educational Psychology Review, 30(2), 373-396. https://doi.org/10.1007/s10648-017-9420-8

52. *Igbokwe, U. L., et al. (2019). Intervention for burnout among english education undergraduates: Implications for curriculum innovation. Medicine, 98(26), e16219. https://doi.org/10.1097/MD.0000000000016219

53. *Jeffcoat, T., \& Hayes, S. C. (2012). A randomized trial of act bibliotherapy on the mental health of k-12 teachers and staff. Behaviour Research and Therapy, 50(9), 571-579. https://doi.org/10.1016/j.brat.2012.05.008

54. Jennings, P. A., \& Greenberg, M. T. (2009). The prosocial classroom: Teacher social and emotional competence in relation to student and classroom outcomes. Review of Educational Research, 79(1), 491-525. https://doi.org/10.3102/0034654308325693

55. *Jennings, P. A., et al. (2011). Improving classroom learning environments by cultivating awareness and resilience in education (care): Results of two pilot studies. Journal of Classroom Interaction, 46(1), 37-48

56. *Jennings, P. A., et al. (2013). Improving classroom learning environments by cultivating awareness and resilience in education (care): Results of a randomized controlled trial. School Psychology Quarterly, 28(4), 374-390. https://doi.org/10.1037/spq0000035

57. *Jennings, P. A., et al. (2017). Impacts of the care for teachers program on teachers' social and emotional competence and classroom interactions. Journal of Educational Psychology, 109(7), 1010-1028. https://doi.org/10.1037/edu0000187

58. *Jennings, P. A., et al. (2019). Long-term impacts of the care program on teachers' self-reported social and emotional competence and well-being. Journal of School Psychology, 76, 186-202. https://doi.org/10.1016/j.jsp.2019.07.009

59. *Johnson, S. M., \& Naidoo, A. V. (2013). Transpersonal practices as prevention intervention for burnout among hiv/aids coordinator teachers. South African Journal of Psychology, 43(1), 59-70. https://doi.org/10.1177/0081246312474406

60. *Johnson, S., \& Naidoo, A. (2017). Can evolutionary insights into the brain's response to threat suggest different group interventions for perceived stress and burnout of teachers in high-risk schools? South African Journal of Psychology, 47(3), 401-415. https://doi.org/10.1177/0081246316675588

61. *Kaspereen, D. (2012). Relaxation intervention for stress reduction among teachers and staff. International Journal of Stress Management, 19(3), 238250. https://doi.org/10.1037/a0029195

62. Klingbeil, D. A., \& Renshaw, T. L. (2018). Mindfulness-based interventions for teachers: A meta-analysis of the emerging evidence base. School Psychology Quarterly, 33(4), 501

63. *Lan, W., et al. (2003). Using music therapy techniques to treat teacher burnout. Journal of Mental Health Counseling, 25(3), $204-217$. https://doi.org/10.17744/mehc.25.3.ghneva55qw5xa3wm

64. *Larsson, G., Setterlind, S., \& Starrin, B. (1990). Routinization of stress control programmes in organizations: A study of swedish teachers. Health Promotion International, 5(4), 269-278. https://doi.org/10.1093/heapro/5.4.269

65. *Leung, S. S., et al. (2011). A brief cognitive-behavioral stress management program for secondary school teachers. Journal of Occupational Health, 53(1), 23-35. https://doi.org/10.1539/joh.110037

66. *Luong, M. T., et al. (2019). Exploring mindfulness benefits for students and teachers in three german high schools. Mindfulness, 10(12), 2682-2702. https://doi.org/10.1007/s12671-019-01231-6

Page $11 / 29$ 
67. *Mazloomy Mahmoodabad, S. S., et al. (2014). The comparison of the effect of transactional model-based teaching and ordinary education curriculumbased teaching programs on stress management among teachers. Global Journal of Health Science, 6(3), 241-248.

https://doi.org/10.5539/gjhs.v6n3p241

68. Miller, R. T., et al. (2008). Do teacher absences impact student achievement? Longitudinal evidence from one urban school district. Educational Evaluation and Policy Analysis, 30(2), 181-200

69. *Miyahara, M., et al. (2017). Mindfulness meditation for future early childhood teachers in japan. Teaching and Teacher Education, 65, $136-144$. https://doi.org/10.1016/j.tate.2017.03.007

70. Moher, D., et al. (2009). Preferred reporting items for systematic reviews and meta-analyses: The prisma statement. PLOS Medicine, 6(7), e1000097. https://doi.org/10.1371/journal.pmed.1000097

71. *Montero-Marin, J., et al. (2021). Teachers "finding peace in a frantic world": An experimental study of self-taught and instructor-led mindfulness program formats on acceptability, effectiveness, and mechanisms. Journal of Educational Psychology, 113(8), 1689-1708. https://doi.org/10.1037/edu0000542

72. *Munday, R., et al. (1995). Stress management training for preservice secondary teachers. Journal of Instructional Psychology, 22(2), 141-145

73. *Nwabuko, L. O., et al. (2020). Effect of rational-emotive adult education intervention on burnout symptoms among primary school teachers in southeast nigeria. Journal of International Medical Research, 48(4), 300060519882204. https://doi.org/10.1177/0300060519882204

74. *Ogba, F. N., et al. (2020). Managing job stress in teachers of children with autism: A rational emotive occupational health coaching control trial. Medicine, 99(36), e21651. https://doi.org/10.1097/MD.0000000000021651

75. Oliveira, S., et al. (2021). A meta-analysis of the impact of social and emotional learning interventions on teachers' burnout symptoms. Educational Psychology Review. https://doi.org/10.1007/s10648-021-09612-x

76. *Onuigbo, L. N., et al. (2018). Effect of rational emotive behavior therapy on stress management and irrational beliefs of special education teachers in nigerian elementary schools. Medicine, 97(37), e12191. https://doi.org/10.1097/MD.0000000000012191

77. Ozamiz-Etxebarria, N., et al. (2021). Prevalence of anxiety, depression, and stress among teachers during the covid-19 pandemic: A rapid systematic review with meta-analysis. Brain sciences, 11(9), 1172

78. Ozamiz-Etxebarria, N., et al. (2021). The psychological state of teachers during the covid-19 crisis: The challenge of returning to face-to-face teaching. Frontiers in Psychology, 11. https://doi.org/10.3389/fpsyg.2020.620718

79. Peters, D. H., et al. (2013). Implementation research: What it is and how to do it. BMJ: British Medical Journal, $347, \mathrm{f6753.}$ https://doi.org/10.1136/bmj.f6753

80. *Pozo-Rico, T., et al. (2020). Teacher training can make a difference: Tools to overcome the impact of covid-19 on primary schools. An experimental study. International Journal of Environmental Research and Public Health, 17(22), 1-23. https://doi.org/10.3390/ijerph17228633

81. Random-effects model (2009). In Introduction to meta-analysis (pp. 69-75). https://doi.org/https://doi.org/10.1002/9780470743386.ch12

82. *Rao, M., et al. (2017). Effects of mind sound resonance technique (yogic relaxation) on psychological states, sleep quality, and cognitive functions in female teachers: A randomized, controlled trial. Advances in Mind-Body Medicine, 31(1), 4-9

83. *Roeser, R. W., et al. (2013). Mindfulness training and reductions in teacher stress and burnout: Results from two randomized, waitlist-control field trials. Journal of Educational Psychology, 105(3), 787-804. https://doi.org/10.1037/a0032093

84. Ronfeldt, M., et al. (2013). How teacher turnover harms student achievement. American educational research journal, 50(1), 4-36. https://doi.org/10.3102/0002831212463813

85. Sanders, E. B. N., \& Stappers, P. J. (2008). Co-creation and the new landscapes of design. CoDesign, 4(1), 5-18. https://doi.org/10.1080/15710880701875068

86. *Schloss, P. J., et al. (1983). Stress reduction for professionals working with aggressive adolescents. Exceptional Children, 49(4), 349-354. https://doi.org/10.1177/001440298304900408

87. *Schnaider-Levi, L., et al. (2020). The effect of inquiry-based stress reduction on teacher burnout: A controlled trial. Brain Sciences, 10(7), 1-9. https://doi.org/10.3390/brainsci10070468

88. Schoenwald, S. K., et al. (2011). Toward the effective and efficient measurement of implementation fidelity. Administration and Policy in Mental Health and Mental Health Services Research, 38(1), 32-43

89. *Schoeps, K., et al. (2019). Effects of emotional skills training to prevent burnout syndrome in schoolteachers. Ansiedad y Estres, 25(1), 7-13. https://doi.org/10.1016/j.anyes.2019.01.002

90. *Sharp, J. J., \& Forman, S. G. (1985). A comparison of two approaches to anxiety management for teachers. Behavior Therapy, 16(4), $370-383$. https://doi.org/http://dx.doi.org/10.1016/S0005-7894\%2885\%2980004-6

91. *Shimazu, A., et al. (2003). Effects of stress management program for teachers in japan: A pilot study. Journal of Occupational Health, 45(4), 202-208. https://doi.org/10.1539/joh.45.202

92. Silva, D. F. O., et al. (2021). Prevalence of anxiety, depression, and stress among teachers during the covid-19 pandemic: A prisma-compliant systematic review.Medicine, $100(44)$

93. *Siu, O. L., et al. (2014). Intervention studies on enhancing work well-being, reducing burnout, and improving recovery experiences among hong kong health care workers and teachers. International Journal of Stress Management, 21(1), 69-84. https://doi.org/10.1037/a0033291

94. *Song, X., et al. (2020). Effects of a four-day mindfulness intervention on teachers' stress and affect: A pilot study in eastern china. Frontiers in Psychology, 11, 1298. https://doi.org/10.3389/fpsyg.2020.01298

Page $12 / 29$ 
95. Sorensen, L. C., \& Ladd, H. F. (2020). The hidden costs of teacher turnover. AERA Open, 6(1), 2332858420905812. https://doi.org/10.1177/2332858420905812

96. *Sottimano, I., et al. (2018). We cannot be "forever young," but our children are: A multilevel intervention to sustain nursery school teachers' resources and well-being during their long work life cycle. PLOS ONE, 13(11), e0206627. https://doi.org/10.1371/journal

97. Steen, M., et al. (2011). Benefits of co-design in service design projects.International Journal of Design, 5(2)

98. Steiner, E. D., \& Woo, A. (2021). Job-related stress threatens the teacher supply: Key findings from the 2021 state of the u.S. Teacher survey. RAND Corporation. https://doi.org/10.7249/RRA1108-1

99. Sterne, J. A. C., et al. (2019). Rob 2: A revised tool for assessing risk of bias in randomised trials. BMJ, 366, I4898

100. Sterne, J. A., et al. (2016). Robins-i: A tool for assessing risk of bias in non-randomised studies of interventions. BMJ, 355, i4919. https://doi.org/10.1136/bmj.i4919

101. Tanner-Smith, E. E., \& Grant, S. (2018). Meta-analysis of complex interventions. Annual Review of Public Health, 39(1), $135-151$. https://doi.org/10.1146/annurev-publhealth-040617-014112

102. *Telles, S., et al. (2018). Increased mental well-being and reduced state anxiety in teachers after participation in a residential yoga program. Medical Science Monitor Basic Research, 24, 105-112. https://doi.org/10.12659/MSMBR.909200

103. *Thephilah Cathrine, R., et al. (2020). Burn-out and stress percipience benefits of a stress management program by autogenic relaxation training for teachers: A pilot study. International Journal of Research in Pharmaceutical Sciences, 11(1), 480-490. https://doi.org/10.26452/ijrps.v11i1.1847

104. Thomson, S., \& Hillman, K. (2020). The teaching and learning international survey 2018. Australian report volume 2: Teachers and school leaders as valued professionals. ttps://research.acer.edu.au/talis/7

105. *Todd, C., et al. (2019). Mixed-methods evaluation comparing the impact of two different mindfulness approaches on stress, anxiety and depression in school teachers. BMJ Open, 9(7), e025686. https://doi.org/10.1136/bmjopen-2018-025686

106. ${ }^{*}$ Tsang, H. W., et al. (2015). A pilot evaluation on a stress management programme using a combined approach of cognitive behavioural therapy (cbt) and complementary and alternative medicine (cam) for elementary school teachers. Stress Health, 31(1), 35-43. https://doi.org/10.1002/smi.2522

107. *Tsang, K. K. Y., et al. (2021). Effectiveness and mechanisms of mindfulness training for school teachers in difficult times: A randomized controlled trial. Mindfulness, 12(11), 2820-2831. https://doi.org/10.1007/s12671-021-01750-1

108. *Tunnecliffe, M. R., et al. (1986). Relative efficacy of using behavioral consultation as an approach to teacher stress management. Journal of School Psychology, 24(2), 123-131. https://doi.org/10.1016/0022-4405\%2886\%2990004-X

109. *Ugwoke, S. C., et al. (2018). A rational-emotive stress management intervention for reducing job burnout and dysfunctional distress among special education teachers: An effect study. Medicine, 97(17), e0475. https://doi.org/10.1097/MD.0000000000010475

110. *Unterbrink, T., et al. (2012). Burnout and effort-reward imbalance improvement for teachers by a manual-based group program. International Archives of Occupational \& Environmental Health, 85(6), 667-674. https://doi.org/10.1007/s00420-011-0712-x

111. Vargas Rubilar, N., \& Oros, L. B. (2021). Stress and burnout in teachers during times of pandemic. Frontiers in Psychology, 12(5586), https://doi.org/10.3389/fpsyg.2021.756007

112. *Vesely, A. K., et al. (2014). El training and pre-service teacher wellbeing. Personality and Individual Differences, 65, 81-85. https://doi.org/10.1016/j.paid.2014.01.052

113. von der Embse, N., et al. (2019). Teacher stress interventions: A systematic review. Psychology in the Schools, 56(8), 1328-1343

114. von Hippel, P. T. (2015). The heterogeneity statistic i2 can be biased in small meta-analyses. BMC Medical Research Methodology, $15(1), 35$. https://doi.org/10.1186/s12874-015-0024-z

115. Werner-Seidler, A., et al. (2017). School-based depression and anxiety prevention programs for young people: A systematic review and meta-analysis. Clinical Psychology Review, 51, 30-47. https://doi.org/https://doi.org/10.1016/j.cpr.2016.10.005

116. *Wimmer, L., et al. (2019). Improving emotion regulation and mood in teacher trainees: Effectiveness of two mindfulness trainings. Brain and Behavior, 9(9), e01390. https://doi.org/10.1002/brb3.1390

117. *Winzelberg, A. J., \& Luskin, F. M. (1999). The effect of a meditation training in stress levels in secondary school teachers. Stress Medicine, 15(2), 69-77. https://doi.org/10.1002/\%28SICI\%291099-1700\%28199904\%2915:2\%3C69. ::AID-SMI787\%3E3.0.CO;2-W

118. *Wu, S., et al. (2006). Intervention on occupational stress among teachers in the middle schools in china. Stress and Health, 22(5), 329-336. https://doi.org/10.1002/smi.1108

119. *Zadok-Gurman, T., et al. (2021). Effect of inquiry-based stress reduction (ibsr) intervention on well-being, resilience and burnout of teachers during the covid-19 pandemic. Int J Environ Res Public Health, 18(7), https://doi.org/10.3390/ijerph18073689

120. Zarate, K., et al. (2019). Meta-analysis of mindfulness training on teacher well-being. Psychology in the Schools, 56(10), 1700-1715

121. Zarski, A. C., et al. (2016). Adherence to internet-based mobile-supported stress management: A pooled analysis of individual participant data from three randomized controlled trials. Journal of Medical Internet Research, 18(6), e146. https://doi.org/10.2196/jmir.4493

122. *Zolnierczyk-Zreda, D. (2005). An intervention to reduce work-related burnout in teachers. International Journal of Occupational Safety \& Ergonomics, 11(4), 423-430. https://doi.org/10.1080/10803548.2005.11076661

\section{Tables}

Table 1 Characteristics of Randomised Controlled Trials in the Review 


\begin{tabular}{|c|c|c|c|c|c|c|c|c|c|c|}
\hline Study & Country & Population & $N$ & $\begin{array}{l}\text { Mean } \\
\text { Age }\end{array}$ & Attrition & Control & Program & $\begin{array}{l}\text { Theoretical } \\
\text { Approach }\end{array}$ & Program Content & $\begin{array}{l}\text { Progra } \\
\text { Sessic }\end{array}$ \\
\hline $\begin{array}{l}\text { Ancona et } \\
\text { al. 2014* }\end{array}$ & USA & $\begin{array}{l}\text { Elementary \& } \\
\text { Middle teachers }\end{array}$ & 47 & NR & 16.00 & $\mathrm{NI}$ & $\begin{array}{l}\text { Holistic Life } \\
\text { Foundation } \\
\text { Yoga \& } \\
\text { Mindfulness } \\
\text { Curriculum }\end{array}$ & $\begin{array}{l}\text { Mindfulness } \\
\text { and/or } \\
\text { relaxation }\end{array}$ & $\begin{array}{l}\text { Yoga \& } \\
\text { Mindfulness } \\
\text { practices to train } \\
\text { awareness and } \\
\text { attention, } \\
\text { including } \\
\text { breathing, } \\
\text { visualisation, } \\
\text { yoga postures, } \\
\text { guided mindful } \\
\text { reflection }\end{array}$ & $\begin{array}{l}\text { 3-weeh } \\
45-\text { mir } \\
\text { sessio }\end{array}$ \\
\hline $\begin{array}{l}\text { Ansley et al. } \\
2021^{\star}\end{array}$ & USA & $\begin{array}{l}\text { Pre-service, } \\
\text { Elementary, \& } \\
\text { Secondary }\end{array}$ & 59 & NR & 6.90 & $\mathrm{NI}$ & $\begin{array}{l}\text { Online stress } \\
\text { intervention }\end{array}$ & $\begin{array}{l}\text { Stress } \\
\text { management } \\
\text { skills }\end{array}$ & $\begin{array}{l}\text { Online stress } \\
\text { program } \\
\text { including } \\
\text { response } \\
\text { activation and } \\
\text { cognitive } \\
\text { restructuring, } \\
\text { self-care, } \\
\text { mindfulness, } \\
\text { relaxation, } \\
\text { relationships at } \\
\text { work, routines } \\
\text { and stress, de- } \\
\text { escalation }\end{array}$ & $\begin{array}{l}\text { 4-week } \\
\text { eight } 3 \\
\text { sessio } \\
\text { deliver } \\
\text { twice } \\
\text { week }\end{array}$ \\
\hline $\begin{array}{l}\text { Au et al. } \\
2016\end{array}$ & $\begin{array}{l}\text { Hong } \\
\text { Kong }\end{array}$ & $\begin{array}{l}\text { Elementary } \\
\text { Secondary, \& } \\
\text { Special Education } \\
\text { teachers }\end{array}$ & 60 & NR & 13.33 & None & $\begin{array}{l}\text { Stress } \\
\text { Management } \\
\text { Program }\end{array}$ & $\begin{array}{l}\text { Cognitive- } \\
\text { behavioural } \\
\text { skills }\end{array}$ & $\begin{array}{l}\text { Cognitive- } \\
\text { behavioural } \\
\text { principles } \\
\text { including } \\
\text { psychoeducation, } \\
\text { identification of } \\
\text { work stress, } \\
\text { cognitive } \\
\text { restructuring }\end{array}$ & $\begin{array}{l}\text { 8-week } \\
\text { eight C } \\
\text { sessio } \\
\text { deliver } \\
\text { weekly }\end{array}$ \\
\hline $\begin{array}{l}\text { Benn et al. } \\
2012^{a}\end{array}$ & USA & $\begin{array}{l}\text { Special Education } \\
\text { teachers and } \\
\text { parents }\end{array}$ & 38 & 45.60 & 26.32 & WL & $\begin{array}{l}\text { SMART-in- } \\
\text { Education } \\
\text { Program }\end{array}$ & $\begin{array}{l}\text { Stress } \\
\text { management } \\
\text { skills }\end{array}$ & $\begin{array}{l}\text { Stress } \\
\text { management and } \\
\text { relaxation } \\
\text { techniques, } \\
\text { based on MBSR } \\
\text { plus emotion } \\
\text { regulation, } \\
\text { forgiveness, } \\
\text { kindness, and } \\
\text { compassion }\end{array}$ & $\begin{array}{l}\text { 12-wet } \\
\text { eight 3 } \\
\text { sessio }\end{array}$ \\
\hline $\begin{array}{l}\text { Berger et al. } \\
2016^{a}\end{array}$ & NZ & $\begin{array}{l}\text { Secondary } \\
\text { teachers, } \\
\text { counsellors, } \\
\text { administrators, } \\
\text { psychologists }\end{array}$ & 69 & 44.57 & 2.86 & None & $\begin{array}{l}\text { ERASE-Stress } \\
\text { New Zealand } \\
\text { Program }\end{array}$ & Other & $\begin{array}{l}\text { Coping skills and } \\
\text { resilience } \\
\text { strategies to deal } \\
\text { with traumatic } \\
\text { stress, including } \\
\text { psychoeducation, } \\
\text { mindfulness, } \\
\text { body-oriented } \\
\text { exercises, art- } \\
\text { therapy, narrative } \\
\text { techniques }\end{array}$ & $\begin{array}{l}3 \text { full c } \\
\text { worksl }\end{array}$ \\
\hline $\begin{array}{l}\text { Bertoch et } \\
\text { al. 1989* }\end{array}$ & USA & $\begin{array}{l}\text { Middle and } \\
\text { Secondary teachers }\end{array}$ & 30 & 38.10 & NR & $\mathrm{NI}$ & $\begin{array}{l}\text { Stress } \\
\text { Management } \\
\text { Program }\end{array}$ & $\begin{array}{l}\text { Stress } \\
\text { management } \\
\text { skills }\end{array}$ & $\begin{array}{l}\text { Psychoeducation, } \\
\text { assertiveness } \\
\text { training, } \\
\text { relaxation and } \\
\text { breathing } \\
\text { strategies, } \\
\text { meditation, self- } \\
\text { care }\end{array}$ & $\begin{array}{l}\text { Twelvt } \\
\text { sessio }\end{array}$ \\
\hline $\begin{array}{l}\text { Biglan et al. } \\
2013^{a}\end{array}$ & USA & $\begin{array}{l}\text { Pre-school } \\
\text { teachers, } \\
\text { assistants, } \\
\text { affiliated family } \\
\text { consultants }\end{array}$ & 28 & NR & 0.00 & WL & $\begin{array}{l}\text { ACT } \\
\text { Workshops }\end{array}$ & ACT & $\begin{array}{l}\text { Sleep education, } \\
\text { including } \\
\text { physiological \& } \\
\text { behavioural } \\
\text { characteristics, } \\
\text { mechanisms of } \\
\text { regulation, sleep } \\
\text { hygiene }\end{array}$ & $\begin{array}{l}\text { 8-week } \\
\text { four 4- } \\
\text { sessio } \\
\text { deliver } \\
\text { fortnig }\end{array}$ \\
\hline $\begin{array}{l}\text { Castillo- } \\
\text { Gualda et } \\
\text { al. } 2017^{a}\end{array}$ & Spain & $\begin{array}{l}\text { Early Childhood, } \\
\text { Elementary \& } \\
\text { Secondary } \\
\text { teachers, managers }\end{array}$ & 54 & 35.98 & 0.00 & $\mathrm{NI}$ & $\begin{array}{l}\text { RULER } \\
\text { Program }\end{array}$ & $\begin{array}{l}\text { Socio- } \\
\text { emotional, } \\
\text { relationship } \\
\text { and/or }\end{array}$ & $\begin{array}{l}\text { Socio-emotional } \\
\text { learning program } \\
\text { focused on } \\
\text { emotional } \\
\text { intelligence skills }\end{array}$ & $\begin{array}{l}\text { 12-wet } \\
\text { eight } 3 \\
\text { sessio }\end{array}$ \\
\hline
\end{tabular}

Page 14/ 29 


\begin{tabular}{|c|c|c|c|c|c|c|c|c|c|c|}
\hline & & & & & & & & $\begin{array}{l}\text { interpersonal } \\
\text { skills }\end{array}$ & & \\
\hline $\begin{array}{l}\text { Cecil et al. } \\
1990^{b}\end{array}$ & USA & $\begin{array}{l}\text { Elementary \& } \\
\text { Middle teachers }\end{array}$ & 54 & NR & NR & $\mathrm{NI}$ & $\begin{array}{l}\text { Stress } \\
\text { Inoculation } \\
\text { Training }\end{array}$ & $\begin{array}{l}\text { Cognitive- } \\
\text { behavioural } \\
\text { skills }\end{array}$ & $\begin{array}{l}\text { Cognitive- } \\
\text { behavioural } \\
\text { principles, } \\
\text { including } \\
\text { psychoeducation, } \\
\text { relaxation } \\
\text { training, cognitive } \\
\text { restructuring }\end{array}$ & $\begin{array}{l}\text { 6-weet } \\
\text { 90-mir } \\
\text { sessio } \\
\text { deliver } \\
\text { weekly }\end{array}$ \\
\hline Chan 2013 & $\begin{array}{l}\text { Hong } \\
\text { Kong }\end{array}$ & $\begin{array}{l}\text { Teachers (type not } \\
\text { specified) }\end{array}$ & 81 & 33.73 & 2.44 & None & $\begin{array}{l}\text { Gratitude } \\
\text { Intervention }\end{array}$ & Other & $\begin{array}{l}\text { "Count-your- } \\
\text { blessings" } \\
\text { activity, involving } \\
\text { keeping weekly } \\
\text { logs of good } \\
\text { things or events }\end{array}$ & 8-week \\
\hline $\begin{array}{l}\text { Cheek et al. } \\
2003\end{array}$ & USA & $\begin{array}{l}\text { Elementary } \\
\text { teachers }\end{array}$ & 51 & NR & NR & None & $\begin{array}{l}\text { Stress } \\
\text { Inoculation } \\
\text { training }\end{array}$ & $\begin{array}{l}\text { Cognitive- } \\
\text { behavioural } \\
\text { skills }\end{array}$ & $\begin{array}{l}\text { Cognitive- } \\
\text { behavioural } \\
\text { principles, } \\
\text { including } \\
\text { psychoeducation, } \\
\text { relaxation } \\
\text { training, cognitive } \\
\text { restructuring }\end{array}$ & 6-week \\
\hline $\begin{array}{l}\text { Cook et al. } \\
2017^{\star}\end{array}$ & USA & $\begin{array}{l}\text { Middle \& } \\
\text { Secondary teachers }\end{array}$ & 44 & NR & NR & $\mathrm{AC}$ & $\begin{array}{l}\text { ACHIEVER } \\
\text { Resilience } \\
\text { Curriculum }\end{array}$ & Other & $\begin{array}{l}\text { Wellbeing } \\
\text { promoting } \\
\text { intervention } \\
\text { based on positive } \\
\text { psychology, } \\
\text { cognitive-- } \\
\text { behavioural } \\
\text { principles, and } \\
\text { ACT }\end{array}$ & $\begin{array}{l}\text { 5-weel } \\
\text { five } 2 . \\
\text { sessio } \\
\text { deliver } \\
\text { weekly }\end{array}$ \\
\hline $\begin{array}{l}\text { Cooley et } \\
\text { al. } 1996^{a, b}\end{array}$ & USA & $\begin{array}{l}\text { Elementary, } \\
\text { Secondary, \& } \\
\text { Middle Special } \\
\text { Education teachers } \\
\text { \& related services } \\
\text { providers }\end{array}$ & 37 & NR & NR & WL & $\begin{array}{l}\text { Stress } \\
\text { Management } \\
\text { Workshops }\end{array}$ & $\begin{array}{l}\text { Cognitive- } \\
\text { behavioural } \\
\text { skills }\end{array}$ & $\begin{array}{l}\text { Cognitive- } \\
\text { behavioural } \\
\text { principles to } \\
\text { develop } \\
\text { situational, } \\
\text { physiological, \& } \\
\text { cognitive coping } \\
\text { skills }\end{array}$ & $\begin{array}{l}\text { 5-weel } \\
\text { five 2-I } \\
\text { worksl } \\
\text { deliver } \\
\text { weekly }\end{array}$ \\
\hline $\begin{array}{l}\text { De } \\
\text { Carvalho et } \\
\text { al. 2021* }\end{array}$ & Portugal & $\begin{array}{l}\text { Elementary } \\
\text { teachers }\end{array}$ & 228 & 43.67 & 8.95 & WL & $\begin{array}{l}\text { Mindfulness- } \\
\text { based program }\end{array}$ & $\begin{array}{l}\text { Mindfulness } \\
\text { and/or } \\
\text { relaxation }\end{array}$ & $\begin{array}{l}\text { Mindfulness } \\
\text { based program } \\
\text { that aims to } \\
\text { promote } \\
\text { teachers' social- } \\
\text { emotional } \\
\text { competencies. } \\
\text { Three } \\
\text { components: } \\
\text { mindfulness } \\
\text { practices to } \\
\text { reduce stress, } \\
\text { emotional self- } \\
\text { regulation, and } \\
\text { caring practices }\end{array}$ & $\begin{array}{l}\text { 10-we } \\
\text { ten } 2.5 \\
\text { sessio } \\
\text { deliver } \\
\text { weekly }\end{array}$ \\
\hline $\begin{array}{l}\text { Dike et al. } \\
2021^{\star}\end{array}$ & Nigeria & $\begin{array}{l}\text { Special Education } \\
\text { teachers }\end{array}$ & 58 & 31.95 & 0.00 & WL & Y-CBT program & $\begin{array}{l}\text { Cognitive- } \\
\text { behavioural } \\
\text { skills }\end{array}$ & $\begin{array}{l}\text { CBT strategies } \\
\text { were blended } \\
\text { with after-session } \\
\text { Yoga exercises. } \\
\text { Based on ABCDE } \\
\text { group therapeutic } \\
\text { model }\end{array}$ & $\begin{array}{l}\text { 12-we } \\
\text { twelve } \\
\text { hour } \\
\text { sessio } \\
\text { deliver } \\
\text { weekly }\end{array}$ \\
\hline $\begin{array}{l}\text { Ebert et al. } \\
2014^{\star}\end{array}$ & Germany & $\begin{array}{l}\text { Teachers (type not } \\
\text { specified) }\end{array}$ & 150 & 47.10 & 18.67 & WL & $\begin{array}{l}\text { Internet-Based } \\
\text { Problem- } \\
\text { Solving } \\
\text { Training }\end{array}$ & $\begin{array}{l}\text { Cognitive- } \\
\text { behavioural } \\
\text { skills }\end{array}$ & $\begin{array}{l}\text { Cognitive- } \\
\text { behavioural } \\
\text { principles, } \\
\text { including } \\
\text { problem-solving, } \\
\text { behavioural } \\
\text { activation, coping } \\
\text { with rumination }\end{array}$ & $\begin{array}{l}5 \text { week } \\
\text { one se } \\
\text { guidec } \\
\text { lesson } \\
\text { weekly }\end{array}$ \\
\hline $\begin{array}{l}\text { Figl-Hertlein } \\
\text { et al. } 2014\end{array}$ & Austria & Secondary teachers & 151 & NR & 39.53 & None & $\begin{array}{l}\text { Individualised } \\
\text { Physiotherapy } \\
\text { Directed } \\
\text { Occupational } \\
\text { Health }\end{array}$ & $\begin{array}{l}\text { Stress } \\
\text { management } \\
\text { skills }\end{array}$ & $\begin{array}{l}\text { Ergonomic and } \\
\text { stress } \\
\text { management } \\
\text { training, } \\
\text { including }\end{array}$ & $\begin{array}{l}\text { 5-mon } \\
\text { six 30- } \\
\text { sessio }\end{array}$ \\
\hline
\end{tabular}




\begin{tabular}{|c|c|c|c|c|c|c|c|c|c|c|}
\hline & & & & & & & $\begin{array}{l}\text { Program } \\
\text { (tailored for } \\
\text { teachers) }\end{array}$ & & $\begin{array}{l}\text { psychoeducation, } \\
\text { relaxation } \\
\text { strategies, rest } \\
\text { and sleep } \\
\text { patterns, } \\
\text { behavioural } \\
\text { activation, body } \\
\text { awareness }\end{array}$ & \\
\hline $\begin{array}{l}\text { Flook et al. } \\
2013^{*}\end{array}$ & USA & $\begin{array}{l}\text { Elementary } \\
\text { teachers }\end{array}$ & 18 & 43.06 & NR & WL & $\begin{array}{l}\text { Modified } \\
\text { MBSR } \\
\text { (adapted for } \\
\text { teachers) }\end{array}$ & $\begin{array}{l}\text { Mindfulness } \\
\text { and/or } \\
\text { relaxation }\end{array}$ & $\begin{array}{l}\text { Psychoeducation } \\
\text { and practices } \\
\text { including body } \\
\text { scan, sitting } \\
\text { meditation, } \\
\text { walking } \\
\text { meditation, } \\
\text { loving-kindness } \\
\text { meditation, } \\
\text { choiceless } \\
\text { awareness, yoga }\end{array}$ & $\begin{array}{l}\text { 8-week } \\
\text { eight } 2 \\
\text { sessio } \\
\text { day } \\
\text { mindf। } \\
\text { immer }\end{array}$ \\
\hline $\begin{array}{l}\text { Franco et } \\
\text { al. } 2010\end{array}$ & Spain & Secondary teachers & 68 & 40.20 & NR & $\mathrm{AC}$ & $\begin{array}{l}\text { Flow } \\
\text { Meditation } \\
\text { Program }\end{array}$ & $\begin{array}{l}\text { Mindfulness } \\
\text { and/or } \\
\text { relaxation }\end{array}$ & $\begin{array}{l}\text { Based on ACT, } \\
\text { including } \\
\text { learning and } \\
\text { practicing flow } \\
\text { meditation, } \\
\text { allowing and } \\
\text { accepting } \\
\text { thoughts, } \\
\text { sensations and } \\
\text { feelings, body-- } \\
\text { scan, metaphors, } \\
\text { mindfulness } \\
\text { (breathing) }\end{array}$ & $\begin{array}{l}\text { 10-wet } \\
\text { ten } 90 \\
\text { sessio }\end{array}$ \\
\hline $\begin{array}{l}\text { Grant et al. } \\
2010^{\star}\end{array}$ & Australia & Secondary teachers & 44 & 43.21 & NR & WL & $\begin{array}{l}\text { Developmental } \\
\text { Coaching }\end{array}$ & $\begin{array}{l}\text { Cognitive- } \\
\text { behavioural } \\
\text { skills }\end{array}$ & $\begin{array}{l}\text { Cognitive- } \\
\text { behavioural } \\
\text { solution-focused } \\
\text { approach to } \\
\text { coaching on goal } \\
\text { attainment, } \\
\text { stress, and } \\
\text { workplace } \\
\text { wellbeing and } \\
\text { resilience }\end{array}$ & $\begin{array}{l}\text { 20-wet } \\
\text { ten ses } \\
\text { deliver } \\
\text { every } \\
\text { weeks }\end{array}$ \\
\hline $\begin{array}{l}\text { Harris et al. } \\
2016^{a}\end{array}$ & USA & $\begin{array}{l}\text { Middle teachers \& } \\
\text { other support staff }\end{array}$ & 64 & 43.00 & 0.00 & WL & $\begin{array}{l}\text { CALM program } \\
\text { for educators }\end{array}$ & $\begin{array}{l}\text { Mindfulness } \\
\text { and/or } \\
\text { relaxation }\end{array}$ & $\begin{array}{l}\text { Yoga and } \\
\text { mindfulness } \\
\text { practices to } \\
\text { promote social- } \\
\text { emotional } \\
\text { competences, } \\
\text { stress } \\
\text { management, } \\
\text { and wellbeing }\end{array}$ & $\begin{array}{l}16-\text { wet } \\
\text { sixty-f, } \\
20-\text { mir } \\
\text { sessio } \\
\text { deliver } \\
\text { days p } \\
\text { week }\end{array}$ \\
\hline $\begin{array}{l}\text { Hwang et } \\
\text { al. } 2019^{a}\end{array}$ & Australia & $\begin{array}{l}\text { Elementary, } \\
\text { Secondary, \& } \\
\text { Special Education } \\
\text { teachers (including } \\
\text { non-teaching roles) }\end{array}$ & 185 & 43.02 & 35.29 & $\mathrm{NI}$ & Reconnected & $\begin{array}{l}\text { Mindfulness } \\
\text { and/or } \\
\text { relaxation }\end{array}$ & $\begin{array}{l}\text { MBI, including } \\
\text { range of } \\
\text { experiential, } \\
\text { physical and } \\
\text { everyday } \\
\text { exercises e.g., } \\
\text { mindful yoga, } \\
\text { walking, eating } \\
\text { and breathing }\end{array}$ & $\begin{array}{l}\text { 8-week } \\
\text { eight C } \\
\text { sessio }\end{array}$ \\
\hline $\begin{array}{l}\text { Igbokwe et } \\
\text { al. 2019* }\end{array}$ & Nigeria & $\begin{array}{l}\text { Pre-service } \\
\text { teachers }\end{array}$ & 96 & 20.72 & 4.17 & $\begin{array}{l}\mathrm{Nl}+ \\
\text { Whatsapp } \\
\text { group }\end{array}$ & REBT & REBT & $\begin{array}{l}\text { Cognitive, } \\
\text { behavioural, and } \\
\text { emotive } \\
\text { techniques to } \\
\text { consciously } \\
\text { change irrational } \\
\text { thoughts and } \\
\text { beliefs, including } \\
\text { reframing, } \\
\text { distraction, } \\
\text { acceptance, } \\
\text { rewards }\end{array}$ & $\begin{array}{l}10 \text {-we } \\
\text { ten } 80 \\
\text { sessio } \\
\text { deliver } \\
\text { twice } \\
\text { week }\end{array}$ \\
\hline $\begin{array}{l}\text { Jeffcoat et } \\
\text { al. } 2012^{a}\end{array}$ & USA & $\begin{array}{l}\text { Early Education, } \\
\text { Elementary, \& } \\
\text { Secondary } \\
\text { teachers, } \\
\text { administrators, }\end{array}$ & 236 & NR & 24.79 & WL & $\begin{array}{l}\text { ACT self-help } \\
\text { book }\end{array}$ & ACT & $\begin{array}{l}\text { Reading self-help } \\
\text { book, Get out of } \\
\text { your mind and } \\
\text { into your life, plus } \\
\text { quizzes }\end{array}$ & $\begin{array}{l}\text { 8-weet } \\
\text { self-gu }\end{array}$ \\
\hline
\end{tabular}


counsellors, \& other

staff

\begin{tabular}{|c|c|c|c|c|c|c|c|c|}
\hline $\begin{array}{l}\text { Jennings et } \\
\text { al. } 2011\end{array}$ & USA & $\begin{array}{l}\text { Pre-service } \\
\text { teachers }\end{array}$ & 43 & 32 & 14.29 & WL & CARE & $\begin{array}{l}\text { Mindfulness } \\
\text { and/or } \\
\text { relaxation }\end{array}$ \\
\hline
\end{tabular}

\begin{tabular}{|c|c|c|c|c|c|c|c|c|c|c|}
\hline & & & & & & & & relaxation & $\begin{array}{l}\text { professional } \\
\text { development } \\
\text { program, } \\
\text { including } \\
\text { emotion skills } \\
\text { instruction, } \\
\text { mindful } \\
\text { awareness, stress } \\
\text { reduction } \\
\text { practices, caring } \\
\text { and listening } \\
\text { practices }\end{array}$ & $\begin{array}{l}\text { long } \\
\text { sessio } \\
\text { over w } \\
\text { interse } \\
\text { phone } \\
\text { coachi }\end{array}$ \\
\hline $\begin{array}{l}\text { Jennings et } \\
\text { al. } 2013^{\star}\end{array}$ & USA & $\begin{array}{l}\text { Early Education, } \\
\text { Elementary, Middle, } \\
\text { \& Secondary } \\
\text { teachers }\end{array}$ & 53 & 36 & 7.41 & WL & CARE & $\begin{array}{l}\text { Mindfulness } \\
\text { and/or } \\
\text { relaxation }\end{array}$ & $\begin{array}{l}\text { Mindfulness- } \\
\text { based } \\
\text { professional } \\
\text { development } \\
\text { program, } \\
\text { including } \\
\text { emotion skills } \\
\text { instruction, } \\
\text { mindful } \\
\text { awareness, stress } \\
\text { reduction } \\
\text { practices, caring } \\
\text { and listening } \\
\text { practices }\end{array}$ & $\begin{array}{l}\text { 4-6 we } \\
\text { four di } \\
\text { long } \\
\text { sessio } \\
\text { with } \\
\text { interse } \\
\text { phone } \\
\text { coachi } \\
\text { plus bi } \\
\text { sessio } \\
\text { month } \\
\text { later }\end{array}$ \\
\hline $\begin{array}{l}\text { Jennings et } \\
\text { al. } 2017 \text {; } \\
2019 \text { follow } \\
\text { up data }\end{array}$ & USA & $\begin{array}{l}\text { Elementary } \\
\text { teachers }\end{array}$ & 224 & NR & 7.00 & WL & CARE & $\begin{array}{l}\text { Mindfulness } \\
\text { and/or } \\
\text { relaxation }\end{array}$ & $\begin{array}{l}\text { Mindfulness- } \\
\text { based } \\
\text { professional } \\
\text { development } \\
\text { program, } \\
\text { including } \\
\text { emotion skills } \\
\text { instruction, } \\
\text { mindful } \\
\text { awareness, stress } \\
\text { reduction } \\
\text { practices, caring } \\
\text { and listening } \\
\text { practices }\end{array}$ & $\begin{array}{l}\text { 4-mon } \\
\text { five 6-ł } \\
\text { trainin } \\
\text { days, } 1 \\
\text { inters } \\
\text { phone } \\
\text { coachi }\end{array}$ \\
\hline
\end{tabular}

\begin{tabular}{|c|c|c|c|c|c|c|c|c|c|c|}
\hline $\begin{array}{l}\text { Kaspereen } \\
\text { et al. } 2012^{a}\end{array}$ & USA & $\begin{array}{l}\text { Secondary } \\
\text { teachers, } \\
\text { assistants, } \\
\text { receptionists, } \\
\text { coaches }\end{array}$ & 54 & 40.65 & 0.00 & $\mathrm{NI}$ & $\begin{array}{l}\text { Structured } \\
\text { Relaxation } \\
\text { Training } \\
\text { customised for } \\
\text { teachers }\end{array}$ & $\begin{array}{l}\text { Mindfulness } \\
\text { and/or } \\
\text { relaxation }\end{array}$ & $\begin{array}{l}\text { Meditation, deep } \\
\text { breathing, } \\
\text { relaxing music }\end{array}$ & $\begin{array}{l}\text { 4-week } \\
\text { four 31 } \\
\text { min } \\
\text { sessio }\end{array}$ \\
\hline $\begin{array}{l}\text { Montero- } \\
\text { Marin et al. } \\
2021\end{array}$ & England & Secondary teachers & 206 & 18.10 & 38.80 & $\mathrm{NI}$ & $\begin{array}{l}\text { Instructor-Led } \\
\text { Mindfulness } \\
\text { Program }\end{array}$ & $\begin{array}{l}\text { Mindfulness- } \\
\text { based } \\
\text { cognitive } \\
\text { therapy }\end{array}$ & $\begin{array}{l}\text { Introductory } \\
\text { skills-based } \\
\text { program using } \\
\text { mindfulness- } \\
\text { based cognitive } \\
\text { for improving } \\
\text { wellbeing. }\end{array}$ & $\begin{array}{l}8 \text { week } \\
\text { eight } 1 \\
\text { hour } \text { w } \\
\text { sessio }\end{array}$ \\
\hline
\end{tabular}

\begin{tabular}{|c|c|c|c|c|c|c|c|c|c|c|}
\hline $\begin{array}{l}\text { Nwabuko et } \\
\text { al. } 2019\end{array}$ & Nigeria & $\begin{array}{l}\text { Elementary } \\
\text { teachers }\end{array}$ & 86 & NR & NR & $\mathrm{NI}$ & REAEI & REBT & $\begin{array}{l}\text { Cognitive- } \\
\text { behavioural } \\
\text { principles, } \\
\text { including } \\
\text { cognitive } \\
\text { restructuring and } \\
\text { relaxation, plus } \\
\text { relaxation }\end{array}$ & $\begin{array}{l}\text { 16-wet } \\
32 \text { 2-h } \\
\text { sessio }\end{array}$ \\
\hline $\begin{array}{l}\text { Ogba et al. } \\
2020 *\end{array}$ & Nigeria & $\begin{array}{l}\text { Special Education } \\
\text { teachers }\end{array}$ & 87 & 32.17 & 4.60 & $\mathrm{NI}$ & REOHC & REBT & $\begin{array}{l}\text { Counselling } \\
\text { aimed to counter } \\
\text { irrational beliefs, } \\
\text { with cognitive, } \\
\text { behavioural, and } \\
\text { emotive } \\
\text { techniques }\end{array}$ & $\begin{array}{l}\text { 12-wet } \\
121-2 \\
\text { sessio } \\
\text { deliver } \\
\text { weekly }\end{array}$ \\
\hline $\begin{array}{l}\text { Onuigbo et } \\
\text { al. } 2018^{\star}\end{array}$ & Nigeria & $\begin{array}{l}\text { Elementary Special } \\
\text { Education teachers }\end{array}$ & 86 & 39.38 & 0.00 & $\mathrm{NI}$ & REBT & REBT & $\begin{array}{l}\text { Cognitive, } \\
\text { behavioural, and } \\
\text { emotive }\end{array}$ & $\begin{array}{l}\text { 12-wet } \\
2490- \\
\text { sessio }\end{array}$ \\
\hline
\end{tabular}




\begin{tabular}{|c|c|c|c|c|c|c|c|c|c|c|}
\hline & & & & & & & & & $\begin{array}{l}\text { techniques to } \\
\text { dispute irrational } \\
\text { beliefs, including } \\
\text { cognitive } \\
\text { reframing, } \\
\text { rational emotive } \\
\text { imagery, } \\
\text { relaxation, } \\
\text { systematic } \\
\text { desensitisation }\end{array}$ & $\begin{array}{l}\text { deliver } \\
\text { twice } \mathrm{f} \\
\text { week }\end{array}$ \\
\hline $\begin{array}{l}\text { Pozo-Rico } \\
\text { et al. } 2020\end{array}$ & Spain & $\begin{array}{l}\text { Elementary } \\
\text { teachers }\end{array}$ & 141 & 38.40 & NR & $\mathrm{NI}$ & REBT & REBT & $\begin{array}{l}\text { Cognitive, } \\
\text { behavioural, and } \\
\text { emotive } \\
\text { techniques to } \\
\text { dispute irrational } \\
\text { beliefs, including } \\
\text { cognitive } \\
\text { reframing, } \\
\text { rational emotive } \\
\text { imagery, } \\
\text { relaxation, } \\
\text { systematic } \\
\text { desensitisation }\end{array}$ & $\begin{array}{l}\text { 12-wet } \\
2490- \\
\text { sessio } \\
\text { deliver } \\
\text { twice } \\
\text { week }\end{array}$ \\
\hline $\begin{array}{l}\text { Rao et al. } \\
2017^{\star}\end{array}$ & India & $\begin{array}{l}\text { Elementary } \\
\text { teachers }\end{array}$ & 60 & 41.50 & 0.00 & $\mathrm{NI}$ & MSRT & $\begin{array}{l}\text { Mindfulness } \\
\text { and/or } \\
\text { relaxation }\end{array}$ & $\begin{array}{l}\text { Mindfulness- } \\
\text { based, yogic } \\
\text { relaxation } \\
\text { technique }\end{array}$ & $\begin{array}{l}\text { 4-week } \\
\text { min } \\
\text { sessio } \\
\text { each d } \\
\text { five tin } \\
\text { per we }\end{array}$ \\
\hline $\begin{array}{l}\text { Roeser et } \\
\text { al. } 2013\end{array}$ & $\begin{array}{l}\text { Canada, } \\
\text { USA }\end{array}$ & $\begin{array}{l}\text { Elementary \& } \\
\text { Secondary teachers }\end{array}$ & 113 & 46.90 & 10.00 & WL & MT & $\begin{array}{l}\text { Mindfulness } \\
\text { and/or } \\
\text { relaxation }\end{array}$ & $\begin{array}{l}\text { Mindfulness- } \\
\text { based, including } \\
5 \text { activities that } \\
\text { increase } \\
\text { compassion and } \\
\text { mindfulness by } \\
\text { directing and } \\
\text { sustaining } \\
\text { attention } \\
\text { intentionally and } \\
\text { nonjudgmentally } \\
\text { on present- } \\
\text { moment } \\
\text { experiences }\end{array}$ & $\begin{array}{l}\text { 8-week } \\
\text { sessio } \\
\text { deliver } \\
\text { over 31 } \\
\text { hours }\end{array}$ \\
\hline $\begin{array}{l}\text { Schloss et } \\
\text { al. } 1983\end{array}$ & USA & $\begin{array}{l}\text { Special Education } \\
\text { teachers \& } \\
\text { associates }\end{array}$ & 14 & 30 & NR & None & $\begin{array}{l}\text { Relaxation } \\
\text { Training and } \\
\text { Systematic } \\
\text { Desensitisation }\end{array}$ & $\begin{array}{l}\text { Stress } \\
\text { management } \\
\text { skills }\end{array}$ & $\begin{array}{l}\text { Progressive } \\
\text { muscle relaxation } \\
\text { and gradual } \\
\text { exposure to } \\
\text { provoking events }\end{array}$ & $\begin{array}{l}\text { 3-mon } \\
32 \text { ses } \\
\text { deliver } \\
\text { three t } \\
\text { per we }\end{array}$ \\
\hline $\begin{array}{l}\text { Schoeps et } \\
\text { al. } 2019^{\text {a }}\end{array}$ & Spain & $\begin{array}{l}\text { Early Childhood, } \\
\text { Kindergarten, } \\
\text { Elementary, \& } \\
\text { Secondary teachers } \\
\text { \& counsellors }\end{array}$ & 340 & 42.64 & NR & $\mathrm{NI}$ & $\begin{array}{l}\text { Emotional } \\
\text { Skills Training }\end{array}$ & $\begin{array}{l}\text { Socio- } \\
\text { emotional, } \\
\text { relationship } \\
\text { and/or } \\
\text { interpersonal } \\
\text { skills }\end{array}$ & $\begin{array}{l}\text { Emotional } \\
\text { abilities and } \\
\text { skills to develop } \\
\text { perception, } \\
\text { expression, } \\
\text { understanding, } \\
\text { and management } \\
\text { of emotions }\end{array}$ & $\begin{array}{l}\text { 3-mon } \\
\text { seven } \\
\text { sessio }\end{array}$ \\
\hline $\begin{array}{l}\text { Sharp et al. } \\
1985^{\star, b}\end{array}$ & USA & $\begin{array}{l}\text { Elementary, Middle, } \\
\text { \& Secondary } \\
\text { teachers }\end{array}$ & 40 & NR & NR & $\mathrm{NI}$ & $\begin{array}{l}\text { Stress } \\
\text { Inoculation } \\
\text { Training } \\
\text { adapted for } \\
\text { Teachers }\end{array}$ & $\begin{array}{l}\text { Cognitive- } \\
\text { behavioural } \\
\text { skills }\end{array}$ & $\begin{array}{l}\text { Psychoeducation, } \\
\text { skill acquisition } \\
\text { including } \\
\text { relaxation and } \\
\text { rational } \\
\text { restructuring, and } \\
\text { rehearsal }\end{array}$ & $\begin{array}{l}\text { 4-week } \\
\text { eight } 2 \\
\text { sessio } \\
\text { deliver } \\
\text { twice r } \\
\text { week }\end{array}$ \\
\hline $\begin{array}{l}\text { Sottimano } \\
\text { et al. } 2018^{\text {b }}\end{array}$ & Italy & Pre-school teachers & 318 & 48.30 & 21.59 & $\mathrm{NI}$ & $\begin{array}{l}\text { Multilevel } \\
\text { Approach } \\
\text { developed for } \\
\text { pre-school } \\
\text { teachers }\end{array}$ & Other & $\begin{array}{l}\text { Three } \\
\text { approaches } \\
\text { including } \\
\text { individual } \\
\text { psychological } \\
\text { counselling, } \\
\text { group worksite } \\
\text { support } \\
\text { intervention (e.g., }\end{array}$ & $\begin{array}{l}\text { Three } \\
\text { min } \\
\text { counsı } \\
\text { sessio } \\
\text { three } 1 \\
\text { min } \\
\text { Worksi } \\
\text { interve } \\
\text { groups }\end{array}$ \\
\hline
\end{tabular}




\begin{tabular}{|c|c|c|c|c|c|c|c|c|c|c|}
\hline & & & & & & & & & $\begin{array}{l}\text { focusing on } \\
\text { group dynamics, } \\
\text { relationships with } \\
\text { colleagues) and } \\
\text { redefinition of } \\
\text { work } \\
\text { environment, } \\
\text { space and } \\
\text { furniture }\end{array}$ & $\begin{array}{l}\text { three } \\
\text { meetir } \\
\text { with } \\
\text { archit€ } \\
\text { redefin } \\
\text { works; }\end{array}$ \\
\hline $\begin{array}{l}\text { Tsang et al. } \\
2021^{\star}\end{array}$ & $\begin{array}{l}\text { Hong } \\
\text { Kong }\end{array}$ & $\begin{array}{l}\text { Elementary, \& } \\
\text { Secondary, Special } \\
\text { Education teachers }\end{array}$ & 186 & 29.55 & 2.15 & $W L$ & $\begin{array}{l}\text { MBSR } \\
\text { MBCT }\end{array}$ & $\begin{array}{l}\text { Mindfulness } \\
\text { and/or } \\
\text { relaxation }\end{array}$ & $\begin{array}{l}\text { Based on core } \\
\text { elements of } \\
\text { MBSR, MBCT } \\
\text { and Mindfulness }\end{array}$ & $\begin{array}{l}\text { 8-week } \\
\text { eight } 1 \\
\text { hour w } \\
\text { sessio }\end{array}$ \\
\hline $\begin{array}{l}\text { Tunnecliffe } \\
\text { et al. } 1986^{b}\end{array}$ & Australia & $\begin{array}{l}\text { Elementary } \\
\text { teachers }\end{array}$ & 14 & NR & NR & WL & $\begin{array}{l}\text { Relaxation } \\
\text { Training }\end{array}$ & $\begin{array}{l}\text { Mindfulness } \\
\text { and/or } \\
\text { relaxation }\end{array}$ & $\begin{array}{l}\text { Stress } \\
\text { psychoeducation } \\
\text { and relaxation } \\
\text { training }\end{array}$ & $\begin{array}{l}\text { 5-week } \\
\text { five } 1.1 \\
\text { sessio } \\
\text { deliver } \\
\text { weekly }\end{array}$ \\
\hline $\begin{array}{l}\text { Ugwoke et } \\
\text { al. 2018* }\end{array}$ & Nigeria & $\begin{array}{l}\text { Special Education } \\
\text { teachers }\end{array}$ & 54 & 36.67 & 0.00 & $\mathrm{WL}$ & RESM & REBT & $\begin{array}{l}\text { Behavioural, } \\
\text { cognitive, and } \\
\text { emotive } \\
\text { techniques, } \\
\text { including } \\
\text { cognitive } \\
\text { restructuring, } \\
\text { goal-setting, } \\
\text { relaxation, } \\
\text { motivational } \\
\text { interviewing, } \\
\text { desensitisation, } \\
\text { and imagery }\end{array}$ & $\begin{array}{l}\text { 12-wet } \\
2090- \\
\text { sessio }\end{array}$ \\
\hline $\begin{array}{l}\text { Unterbrink } \\
\text { et al. 2021* }\end{array}$ & Germany & Secondary teachers & 337 & 46.95 & 34.50 & WL & $\begin{array}{l}\text { Professional } \\
\text { Relationships } \\
\text { Intervention }\end{array}$ & $\begin{array}{l}\text { Socio- } \\
\text { emotional, } \\
\text { relationship } \\
\text { and/or } \\
\text { interpersonal } \\
\text { skills }\end{array}$ & $\begin{array}{l}\text { Stress } \\
\text { psychoeducation, } \\
\text { relaxation } \\
\text { training, } \\
\text { authenticity and } \\
\text { role identification, } \\
\text { relationships, and } \\
\text { social support }\end{array}$ & $\begin{array}{l}10-\mathrm{mo} \\
1090- \\
\text { sessio }\end{array}$ \\
\hline $\begin{array}{l}\text { Wu et al. } \\
2006\end{array}$ & China & Middle teachers & 961 & 50.50 & NR & NR & $\begin{array}{l}\text { Organisational } \\
\text { and Individual } \\
\text { Level Stress } \\
\text { Management }\end{array}$ & $\begin{array}{l}\text { Stress } \\
\text { management } \\
\text { skills }\end{array}$ & $\begin{array}{l}\text { Organisational- } \\
\text { level strategies to } \\
\text { modify/diminish } \\
\text { sources of stress } \\
\text { at work, including } \\
\text { redesigning tasks } \\
\text { or flexible } \\
\text { working, and } \\
\text { individual stress } \\
\text { management } \\
\text { skills including } \\
\text { psychoeducation, } \\
\text { relaxation } \\
\text { techniques, } \\
\text { cognitive coping } \\
\text { skills, and } \\
\text { work/lifestyle } \\
\text { modification } \\
\text { skills }\end{array}$ & $\begin{array}{l}\text { Lectur } \\
\text { presen } \\
\text { twice } \\
\text { month } \\
\text { the firs } \\
\text { of the } \\
\text { then o } \\
\text { per mo } \\
\text { for the } \\
\text { remair }\end{array}$ \\
\hline $\begin{array}{l}\text { Zolnierczyk- } \\
\text { Zreda } \\
2005^{\star}\end{array}$ & Poland & $\begin{array}{l}\text { Teachers (type not } \\
\text { specified) }\end{array}$ & 59 & 41.80 & 3.33 & $\mathrm{NI}$ & $\begin{array}{l}\text { Stress } \\
\text { Management } \\
\text { Workshop }\end{array}$ & $\begin{array}{l}\text { Stress } \\
\text { management } \\
\text { skills }\end{array}$ & $\begin{array}{l}\text { Cognitive- } \\
\text { behavioural } \\
\text { methods of } \\
\text { overcoming } \\
\text { workload (e.g., } \\
\text { time } \\
\text { management and } \\
\text { priority setting } \\
\text { skills), enhancing } \\
\text { mastery (e.g., } \\
\text { developing } \\
\text { positive meaning } \\
\text { of work), } \\
\text { relationships } \\
\text { (e.g., } \\
\text { interpersonal and } \\
\text { communication } \\
\text { skills) }\end{array}$ & $\begin{array}{l}\text { 2-days } \\
\text { hrs pel }\end{array}$ \\
\hline
\end{tabular}

Note. * - Studies included in the meta-analysis; ${ }^{a}$ includes samples other than teachers, including counsellors/psychologists, administrative staff, principals, parents, affiliated family consultants, managers, learning support etc. $N$, mean ages, and dropout reported in Table 1 for these studies only include teachers when possible; ${ }^{b=}$ These studies included more than one intervention group. Only the relevant intervention was selected for inclusion in this review and meta- 
analysis, which is reported in Table 1 (see "Program" column). The total sample sizes reported for these studies only include the relevant intervention and the control group/s. The mean ages and dropout reported in Table 1 for these studies only include the relevant groups if they were reported. NR=information not reported. $\mathbf{N}$ - Total number of participants randomly allocated to groups. Mean Age - Mean age of the allocated sample at baseline, unless otherwise specified. Attrition - Number of participants lost to drop out in the intervention group only, measured after the final follow up measurement time point. Control

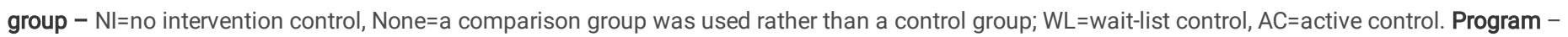
$\mathrm{ACT}=$ Acceptance and Commitment Therapy; RULER=Recognising, Understanding, Labelling, Expressing, and Regulating Emotion; MBSR=Mindfulness Based Stress Reduction; CALM=Community Approach to Learning Mindfully; MBI=Mindfulness-Based Intervention; REBT=Rational Emotive Behaviour Therapy; $\mathrm{CARE}=$ Cultivating Awareness and Resilience in Education; REAEI=Rational-Emotive Adult Education Intervention Programme; REOHC=Rational Emotive Occupational Health Coaching; MSRT=Mind Sound Resonance Technique; MT=Mindfulness Training; RESM=Rational-Emotive Stress Management. Outcome Measures - MBI-EE=Maslach Burnout Inventory - Emotional Exhaustion Subscale; TSI=Teacher Stress Inventory; PSS=Perceived Stress Scale; PWBIA=Personal Well Being Index - Adult; STAI-S=State-Trait Anxiety Inventory - State Subscale; CES-D=Center for Epidemiological Studies Depression Scale; PANAS-P=Positive and Negative Affect Scale - Positive; PANAS-N=Positive and Negative Affect - Negative; PCL-C=Posttraumatic Check List S, ProQOL=Professional Quality of Life Scale; CDRS=Connor-Davidson Resilience Scale; OSI=Occupational Stress Inventory; JSS=Job Satisfaction Scale; ITS=Index of Teaching Stress; TSI-EM=Teacher Stress Inventory - Emotional Manifestations; JSSS-JS=Job Stress in the School Setting - Job Satisfaction; SWLS=Satisfaction with Life Scale; SWS=Satisfaction with Work Scale; MSQ-20=Minnesota Satisfaction Questionnaire -20 items; SF-36 MCS=Short Form 36 Health Survey - Mental Health Component Score; SF-12 MCS=Short Form 12 Health Survey - Mental Health Component Score; PSWQ=Penn State Worry Questionnaire; SC 90-R=Symptom Checklist 90-R; MBI-ES=Maslach Burnout Inventory - Educator Survey; MBI-ES-EE=Maslach Burnout Inventory - Educator Survey - Emotional Exhaustion Subscale; DASS-D=Depression Anxiety Stress Scale - Depression Subscale; DASS-A=Depression Anxiety Stress Scale Anxiety Subscale; DASS-S=Depression Anxiety Stress Scale - Stress Subscale; WWBI=Workplace Well-Being Index; CHS=Cognitive Hardiness Scale; SRIS=Sleep-Related Impairment Scale; PSQI=Pittsburgh Sleep Quality Index; OLBI-S-E=Oldenburg Burnout Inventory for Students - Exhaustion Subscale; PHQ8=Patient Health Questionnaire 8-item Depression Scale; GAD-7=Generalised Anxiety Disorder 7-item Scale; PROMIS-SDQ=PROMIS Sleep Disorder Questionnaire; WEMWBS=The Warwick-Edinburgh Mental Well-being Scale - 14 items; TBI=Teachers' Burnout Inventory; OSI=Occupational Stress Index; TSQ=Teacher Stress Questionnaire; GHQ-12=General Health Questionnaire; PFS=Piper Fatigue Scale; BDI=Beck Depression Inventory; SBI-PE=Spanish Burnout Inventory - Psychological Exhaustion Subscale; TOSQ=Teacher Occupational Stress Factor Questionnaire; TBS-E=Teacher Burnout Scale - Exhaustion Subscale; PED=Profile of Emotional Distress; TBS-EE=Teacher Burnout Scale - Emotional Exhaustion; OSI-R-PS=Occupational Stress Index - Revised Personal Strain Subscale.

\section{Table 2.}

Characteristics of Included Non-Randomised Controlled Trials in the Review 


\begin{tabular}{|c|c|c|c|c|c|c|c|c|c|c|}
\hline Study & Country & Population & $N$ & $\begin{array}{l}\text { Mean } \\
\text { Age }\end{array}$ & Attrition & Control & Program & $\begin{array}{l}\text { Theoretical } \\
\text { Approach }\end{array}$ & Program Content & $\begin{array}{l}\text { Progra } \\
\text { Sessic }\end{array}$ \\
\hline $\begin{array}{l}\text { Berkovich- } \\
\text { Ohana et al. } \\
2020\end{array}$ & Israel & Elementary teachers & 39 & NR & NR & None & MBI & $\begin{array}{l}\text { Mindfulness } \\
\text { and/or } \\
\text { relaxation }\end{array}$ & $\begin{array}{l}\text { Applied mindful } \\
\text { pedagogy for } \\
\text { educators, } \\
\text { including } \\
\text { psychoeducation, } \\
\text { experiential \& } \\
\text { mindful practices } \\
\text { (e.g., body scan, } \\
\text { monitoring } \\
\text { experiences) }\end{array}$ & $\begin{array}{l}\text { 3-mon } \\
\text { ten } \\
\text { sessio } \\
\text { deliver } \\
\text { over 31 }\end{array}$ \\
\hline $\begin{array}{l}\text { Beshai et al. } \\
2015^{a}\end{array}$ & England & $\begin{array}{l}\text { Secondary teachers } \\
\text { \& staff with direct } \\
\text { contact with } \\
\text { students }\end{array}$ & 108 & NR & 17.59 & WL & $\begin{array}{l}\text { b. } \\
\text { Foundations } \\
\text { Course }\end{array}$ & $\begin{array}{l}\text { Mindfulness } \\
\text { and/or } \\
\text { relaxation }\end{array}$ & $\begin{array}{l}\text { Based on MBSR } \\
+ \text { MBCT }\end{array}$ & $\begin{array}{l}\text { 8-week } \\
\text { nine 7! } \\
\text { sessio } \\
\text { deliver } \\
\text { fortnig }\end{array}$ \\
\hline $\begin{array}{l}\text { Carroll et al. } \\
2021\end{array}$ & Australia & $\begin{array}{l}\text { Elementary \& } \\
\text { Secondary teachers }\end{array}$ & 83 & 45.28 & 7.14 & None & MBSR & $\begin{array}{l}\text { Mindfulness } \\
\text { and/or } \\
\text { relaxation }\end{array}$ & $\begin{array}{l}\text { Guided } \\
\text { progressive } \\
\text { mindfulness } \\
\text { meditation } \\
\text { practices, body } \\
\text { awareness } \\
\text { training and } \\
\text { gentle yoga }\end{array}$ & $\begin{array}{l}\text { 8-week } \\
\text { 2.5-hr } \\
\text { sessio } \\
\text { deliver } \\
\text { weekly } \\
\text { (plus a } \\
\text { day ret } \\
\text { in wee } \\
\text { or 6) }\end{array}$ \\
\hline $\begin{array}{l}\text { Castillo-Gualda } \\
\text { et al. } 2019^{a}\end{array}$ & Spain & $\begin{array}{l}\text { Kindergarten, } \\
\text { Elementary \& } \\
\text { Secondary teachers } \\
\text { \& counsellors }\end{array}$ & 59 & 41.12 & 0.00 & $\mathrm{NI}$ & RULER & $\begin{array}{l}\text { Socio- } \\
\text { emotional, } \\
\text { relationship, } \\
\text { and/or } \\
\text { interpersonal } \\
\text { skills }\end{array}$ & $\begin{array}{l}\text { SEL, including } \\
\text { emotional } \\
\text { awareness, } \\
\text { vocabulary, } \\
\text { expression, \& } \\
\text { regulation }\end{array}$ & $\begin{array}{l}\text { 12-wet } \\
\text { eight } 3 \\
\text { sessio }\end{array}$ \\
\hline $\begin{array}{l}\text { Cheng et al. } \\
2021\end{array}$ & China & $\begin{array}{l}\text { Kindergarten } \\
\text { teachers }\end{array}$ & 70 & 30.96 & 0.00 & NR & $\begin{array}{l}\text { Mindfulness } \\
\text { Training } \\
\text { Program }\end{array}$ & $\begin{array}{l}\text { Mindfulness } \\
\text { and/or } \\
\text { relaxation }\end{array}$ & $\begin{array}{l}\text { Based on MBSR } \\
+ \text { MBCT }\end{array}$ & $\begin{array}{l}\text { 4-week } \\
\text { four } 1 . \\
\text { sessio } \\
\text { deliver } \\
\text { weekly }\end{array}$ \\
\hline $\begin{array}{l}\text { Cicotto et al. } \\
2014^{*}\end{array}$ & Italy & Elementary teachers & 126 & 45.00 & 0.00 & $\mathrm{NI}$ & $\begin{array}{l}\text { Psychosocial } \\
\text { Training }\end{array}$ & $\begin{array}{l}\text { Socio- } \\
\text { emotional, } \\
\text { relationship, } \\
\text { and/or } \\
\text { interpersonal } \\
\text { skills }\end{array}$ & $\begin{array}{l}\text { Work-related } \\
\text { stress \& coping } \\
\text { strategies, group } \\
\text { dynamics, } \\
\text { communication, } \\
\text { problem-solving, } \\
\text { decision-making }\end{array}$ & $\begin{array}{l}\text { 16-wet } \\
\text { 3-hr } \\
\text { modul } \\
\text { flexiblt } \\
\text { deliver } \\
\text { freque }\end{array}$ \\
\hline $\begin{array}{l}\text { Dahal \& } \\
\text { Pradhan 2018* }\end{array}$ & India & Secondary teachers & 62 & 37.42 & NR & WL & $\begin{array}{l}\text { Cyclic } \\
\text { Meditation }\end{array}$ & $\begin{array}{l}\text { Mindfulness } \\
\text { and/or } \\
\text { relaxation }\end{array}$ & $\begin{array}{l}\text { Meditation } \\
\text { practice including } \\
\text { prayer, relaxation, } \\
\text { centering, sitting } \\
\text { asanas }\end{array}$ & $\begin{array}{l}\text { 4-week } \\
\text { twenty } \\
\text { sessio } \\
\text { deliver } \\
\text { daily }\end{array}$ \\
\hline $\begin{array}{l}\text { de Souza et al. } \\
2016^{\star}\end{array}$ & Brazil & $\begin{array}{l}\text { Elementary \& } \\
\text { Secondary teachers }\end{array}$ & 84 & 45.50 & 55.17 & WL & $\begin{array}{l}\text { Sleep } \\
\text { Education } \\
\text { Program }\end{array}$ & Other & $\begin{array}{l}\text { Sleep education, } \\
\text { including } \\
\text { physiological \& } \\
\text { behavioural } \\
\text { characteristics, } \\
\text { mechanisms of } \\
\text { regulation, sleep } \\
\text { hygiene }\end{array}$ & $\begin{array}{l}\text { 8-week } \\
\text { four 4- } \\
\text { sessio } \\
\text { deliver } \\
\text { fortnig }\end{array}$ \\
\hline $\begin{array}{l}\text { Dicke et al. } \\
2015^{\star, b}\end{array}$ & Germany & Pre-service teachers & 61 & 27.60 & 42.86 & WL & $\begin{array}{l}\text { Stress } \\
\text { Management } \\
\text { Training }\end{array}$ & $\begin{array}{l}\text { Stress } \\
\text { management } \\
\text { skills }\end{array}$ & $\begin{array}{l}\text { Based on } \\
\text { German AGIL } \\
\text { Training, } \\
\text { including } \\
\text { Psychoeducation, } \\
\text { stress \& time } \\
\text { management } \\
\text { strategies, PMR }\end{array}$ & $\begin{array}{l}\text { Two 8. } \\
\text { sessio }\end{array}$ \\
\hline $\begin{array}{l}\text { Dyer et al. } \\
2020^{\mathrm{a}}\end{array}$ & USA & $\begin{array}{l}\text { Education } \\
\text { professionals }\end{array}$ & 31 & 47.50 & 22.22 & WL & RISE program & $\begin{array}{l}\text { Mindfulness } \\
\text { and/or }\end{array}$ & $\begin{array}{l}\text { Psychoeducation, } \\
\text { guided }\end{array}$ & $\begin{array}{l}\text { 3-day } \\
\text { resider }\end{array}$ \\
\hline
\end{tabular}




\begin{tabular}{|c|c|c|c|c|c|c|c|c|c|c|}
\hline $\begin{array}{l}\text { Fabbro et al. } \\
2020^{\star}\end{array}$ & Italy & $\begin{array}{l}\text { Kindergarten, } \\
\text { Elementary \& } \\
\text { Middle teachers }\end{array}$ & 39 & 50.81 & 0.00 & WL & MOM & $\begin{array}{l}\text { Mindfulness } \\
\text { and/or } \\
\text { relaxation }\end{array}$ & $\begin{array}{l}\text { Psychoeducation, } \\
\text { mindfulness } \\
\text { meditation } \\
\text { techniques } \\
\text { including mindful } \\
\text { breathing, body } \\
\text { scan, observation } \\
\text { of states of mind }\end{array}$ & $\begin{array}{l}\text { 8-week } \\
\text { eight 1 } \\
\text { sessio } \\
\text { deliver } \\
\text { weekly }\end{array}$ \\
\hline Forman $1982^{\star}$ & USA & Secondary teachers & 30 & NR & 20.00 & WL & CB-SMP & $\begin{array}{l}\text { Cognitive- } \\
\text { behavioural } \\
\text { skills }\end{array}$ & $\begin{array}{l}\text { Based on stress } \\
\text { inoculation, } \\
\text { including } \\
\text { psychoeducation, } \\
\text { relaxation, } \\
\text { cognitive } \\
\text { restructuring }\end{array}$ & $\begin{array}{l}\text { 6-week } \\
\text { 3-hr } \\
\text { sessio } \\
\text { deliver } \\
\text { weekly }\end{array}$ \\
\hline $\begin{array}{l}\text { Frank et al. } \\
2015^{a}\end{array}$ & USA & $\begin{array}{l}\text { Secondary teachers, } \\
\text { counsellors, } \\
\text { principals, nurses, } \\
\text { librarians }\end{array}$ & 36 & 40.72 & NR & WL & MBSR & $\begin{array}{l}\text { Mindfulness } \\
\text { and/or } \\
\text { relaxation }\end{array}$ & $\begin{array}{l}\text { Mindfulness } \\
\text { meditation, } \\
\text { including body } \\
\text { scan \& } \\
\text { awareness }\end{array}$ & $\begin{array}{l}\text { 8-week } \\
\text { eight } 2 \\
\text { sessio } \\
\text { deliver } \\
\text { weekly }\end{array}$ \\
\hline
\end{tabular}

$\begin{array}{lllllllll}\text { Friedman et al. } & \text { USA } & \text { Elementary \& } & 85 & 35.00 & \text { NR } & \text { NR } & \text { Stress } & \text { Cognitive- }\end{array}$

1983 Secondary teachers 85 Management behavioural skills \& relaxation two to skills $\quad$ skills for stress 2 -hr

sessio

either

deliver weekly selfdirecte

\begin{tabular}{|c|c|c|c|c|c|c|c|c|c|c|}
\hline $\begin{array}{l}\text { Goetz et al. } \\
2013^{*}\end{array}$ & Germany & $\begin{array}{l}\text { Teachers (type not } \\
\text { specified) }\end{array}$ & 95 & 47.40 & 17.64 & $\mathrm{NI}$ & $\begin{array}{l}\text { AFA Breathing } \\
\text { Therapy }\end{array}$ & $\begin{array}{l}\text { Mindfulness } \\
\text { and/or } \\
\text { relaxation }\end{array}$ & $\begin{array}{l}\text { Holistic approach } \\
\text { with focus on } \\
\text { perception of } \\
\text { breathing, } \\
\text { including } \\
\text { listening to } \\
\text { breath, } \\
\text { experiencing the } \\
\text { body during } \\
\text { movement \& } \\
\text { relaxation, } \\
\text { continuous } \\
\text { mindfulness }\end{array}$ & $\begin{array}{l}11 \text { ses } \\
\text { deliver } \\
\text { weekly }\end{array}$ \\
\hline $\begin{array}{l}\text { Gouda et al., } \\
2016\end{array}$ & Germany & Secondary teachers & 29 & 45.90 & 0.00 & WL & MBSR & $\begin{array}{l}\text { Mindfulness } \\
\text { and/or } \\
\text { relaxation }\end{array}$ & $\begin{array}{l}\text { Psychoeducation } \\
\text { \& mindfulness } \\
\text { meditation, } \\
\text { including body } \\
\text { scan \& } \\
\text { awareness }\end{array}$ & $\begin{array}{l}\text { 8-week } \\
\text { eight } 2 \\
\text { sessio } \\
\text { deliver } \\
\text { weekly }\end{array}$ \\
\hline Hall et al., 1997 & NR & Pre-service teachers & $84^{\mathrm{a}}$ & NR & $2.38^{a}$ & $\mathrm{NI}$ & $\begin{array}{l}\text { Human } \\
\text { Relations } \\
\text { Training }\end{array}$ & $\begin{array}{l}\text { Socio- } \\
\text { emotional, } \\
\text { relationship, } \\
\text { and/or } \\
\text { interpersonal } \\
\text { skills }\end{array}$ & $\begin{array}{l}\text { Interpersonal } \\
\text { skills } \\
\text { development, } \\
\text { counselling skills, } \\
\text { Rogerian style } \\
\text { process group }\end{array}$ & $\begin{array}{l}2 \text {-year } \\
\text { course } \\
\text { conse } \\
10 \text {-wet } \\
\text { terms) } \\
\text { hrs } \\
\text { deliver } \\
\text { weekly }\end{array}$ \\
\hline Johnson \& & South & Secondary teachers & 26 & NR & NR & $\mathrm{NI}$ & Transpersonal & Other & Emotion-oriented & 10-wet \\
\hline
\end{tabular}




\begin{tabular}{|c|c|c|c|c|c|c|c|c|c|c|}
\hline $\begin{array}{l}\text { Naidoo } \\
2017^{*}, b\end{array}$ & Africa & & & & & & $\begin{array}{l}\text { Psychology } \\
\text { Workshops }\end{array}$ & & $\begin{array}{l}\text { intervention, } \\
\text { including } \\
\text { mindfulness, } \\
\text { visualisation }\end{array}$ & $\begin{array}{l}\text { ten } 1.5 \\
\text { sessio } \\
\text { deliver } \\
\text { weekly }\end{array}$ \\
\hline $\begin{array}{l}\text { Johnson \& } \\
\text { Naidoo 2013* }\end{array}$ & $\begin{array}{l}\text { South } \\
\text { Africa }\end{array}$ & $\begin{array}{l}\text { Elementary \& } \\
\text { Secondary teachers }\end{array}$ & 57 & NR & 10.00 & $\mathrm{NI}$ & $\begin{array}{l}\text { Transpersonal } \\
\text { Psychology } \\
\text { Workshops }\end{array}$ & Other & $\begin{array}{l}\text { Emotion-oriented } \\
\text { intervention, } \\
\text { including } \\
\text { mindfulness, } \\
\text { visualisation }\end{array}$ & $\begin{array}{l}6 \text { days } \\
\text { sessio } \\
\text { deliver } \\
\text { daily }\end{array}$ \\
\hline $\begin{array}{l}\text { Larsson et al. } \\
\text { 1990* }\end{array}$ & Sweden & Secondary teachers & 118 & 42.33 & 34.12 & $\mathrm{NI}$ & $\begin{array}{l}\text { Stress Control } \\
\text { Programme }\end{array}$ & $\begin{array}{l}\text { Stress } \\
\text { management } \\
\text { skills }\end{array}$ & $\begin{array}{l}\text { Cognitive- } \\
\text { behavioural } \\
\text { strategies, } \\
\text { including } \\
\text { psychoeducation } \\
\text { \& relaxation } \\
\text { exercises }\end{array}$ & $\begin{array}{l}\text { Five to } \\
\text { eight } 1 \\
\text { sessio } \\
\text { deliver } \\
\text { 2-3-we } \\
\text { interva }\end{array}$ \\
\hline $\begin{array}{l}\text { Leung et al. } \\
2011^{\star}\end{array}$ & China & Secondary teachers & 161 & NR & NR & WL & Brief CB-SMP & $\begin{array}{l}\text { Cognitive- } \\
\text { behavioural } \\
\text { skills }\end{array}$ & $\begin{array}{l}\text { Psychoeducation, } \\
\text { cognitive- } \\
\text { behavioural } \\
\text { therapy principles } \\
\text { including thought } \\
\text { identification and } \\
\text { restructuring, } \\
\text { pleasurable } \\
\text { activities, \& } \\
\text { relaxation }\end{array}$ & 1 sess \\
\hline $\begin{array}{l}\text { Luong et al. } \\
2019^{*}\end{array}$ & Germany & Secondary teachers & 96 & 45.16 & 8.00 & WL & MBSR & $\begin{array}{l}\text { Mindfulness } \\
\text { and/or } \\
\text { relaxation }\end{array}$ & $\begin{array}{l}\text { Mindfulness } \\
\text { meditation, } \\
\text { including body } \\
\text { scan \& } \\
\text { awareness }\end{array}$ & $\begin{array}{l}\text { 8-week } \\
\text { eight } 2 \\
\text { sessio } \\
\text { deliver } \\
\text { weekly }\end{array}$ \\
\hline $\begin{array}{l}\text { Mahmoodabad } \\
\text { et al. } 2014^{\star}\end{array}$ & Iran & Elementary teachers & 200 & 41.65 & NR & None & $\begin{array}{l}\text { Transactional } \\
\text { Model Based } \\
\text { Teaching } \\
\text { Program }\end{array}$ & $\begin{array}{l}\text { Socio- } \\
\text { emotional, } \\
\text { relationship, } \\
\text { and/or } \\
\text { interpersonal } \\
\text { skills }\end{array}$ & $\begin{array}{l}\text { Cognitive- } \\
\text { behavioural } \\
\text { strategies, } \\
\text { including } \\
\text { psychoeducation, } \\
\text { coping strategies, } \\
\text { self-efficacy, time } \\
\text { management, } \\
\text { social } \\
\text { relationships, } \\
\text { physical stress } \\
\text { management }\end{array}$ & $\begin{array}{l}\text { Eight } 1 \\
\text { hr sess }\end{array}$ \\
\hline $\begin{array}{l}\text { Miyahara et al., } \\
2017\end{array}$ & Japan & Pre-service teachers & 60 & NR & 33.33 & None & $\begin{array}{l}\text { Sitting } \\
\text { Meditation }\end{array}$ & $\begin{array}{l}\text { Mindfulness } \\
\text { and/or } \\
\text { relaxation }\end{array}$ & $\begin{array}{l}\text { Based on guided } \\
\text { mindfulness } \\
\text { meditation }\end{array}$ & $\begin{array}{l}\text { One } 3 \text { ? } \\
\text { sessio }\end{array}$ \\
\hline $\begin{array}{l}\text { Munday et al., } \\
1995\end{array}$ & USA & Pre-service teachers & 35 & NR & NR & $\mathrm{NI}$ & $\begin{array}{l}\text { Stress } \\
\text { Management } \\
\text { Training }\end{array}$ & $\begin{array}{l}\text { Stress } \\
\text { management } \\
\text { skills }\end{array}$ & $\begin{array}{l}\text { Cognitive- } \\
\text { behavioural } \\
\text { strategies, } \\
\text { including } \\
\text { psychoeducation, } \\
\text { breathing } \\
\text { techniques, } \\
\text { stretching, } \\
\text { cognitive skills, } \\
\text { PMR, relaxation, } \\
\text { mental quieting }\end{array}$ & $\begin{array}{l}\text { 2-week } \\
\text { four } \\
\text { sessio } \\
\text { (5hr in } \\
\text { total), } \\
\text { deliver } \\
\text { twice } \mathrm{F} \\
\text { week }\end{array}$ \\
\hline $\begin{array}{l}\text { Schnaider-Levi } \\
\text { et al. } 2020\end{array}$ & Israel & Secondary teachers & 60 & 46.40 & NR & $\mathrm{NI}$ & IBSR & $\begin{array}{l}\text { Cognitive- } \\
\text { behavioural } \\
\text { skills }\end{array}$ & $\begin{array}{l}\text { Cognitive } \\
\text { reframing } \\
\text { program, } \\
\text { including thought } \\
\text { identification \& } \\
\text { challenging, } \\
\text { guided reflection }\end{array}$ & $\begin{array}{l}\text { 12-wet } \\
124.5 \\
\text { sessio } \\
\text { deliver } \\
\text { weekly } \\
\text { (3.5hr } \\
\text { group } \\
\text { individ }\end{array}$ \\
\hline $\begin{array}{l}\text { Shimazu et al. } \\
\text { 2003* }\end{array}$ & Japan & $\begin{array}{l}\text { Elementary \& } \\
\text { Secondary teachers }\end{array}$ & 24 & 44.40 & 33.33 & WL & $\begin{array}{l}\text { Stress } \\
\text { Management } \\
\text { Program }\end{array}$ & $\begin{array}{l}\text { Stress } \\
\text { management } \\
\text { skills }\end{array}$ & $\begin{array}{l}\text { Combined } \\
\text { cognitive } \\
\text { behavioural } \\
\text { training \& } \\
\text { relaxation } \\
\text { training, } \\
\text { including } \\
\text { psychoeducation, }\end{array}$ & $\begin{array}{l}\text { Five 2- } \\
\text { sessio } \\
\text { deliver } \\
2-4 \text { we } \\
\text { interva }\end{array}$ \\
\hline
\end{tabular}


PMR, coping

strategies to

manage

classroom

stressors

\begin{tabular}{|c|c|c|c|c|c|c|c|c|c|c|}
\hline Siu et al 2014* & $\begin{array}{l}\text { Hong } \\
\text { Kong }\end{array}$ & $\begin{array}{l}\text { Elementary \& } \\
\text { Secondary teachers }\end{array}$ & 100 & 38.58 & 0.00 & NR & $\begin{array}{l}\text { Stress } \\
\text { Management } \\
\text { Program }\end{array}$ & $\begin{array}{l}\text { Stress } \\
\text { management } \\
\text { skills }\end{array}$ & $\begin{array}{l}\text { Psychoeducation, } \\
\& \text { skills drawn } \\
\text { from cognitive } \\
\text { behavioural } \\
\text { therapy, emotion } \\
\text { regulation, } \\
\text { positive } \\
\text { psychology, \& } \\
\text { conflict } \\
\text { management } \\
\text { (e.g., relaxation, } \\
\text { mindfulness, } \\
\text { effective } \\
\text { communication, } \\
\text { \& recovery) }\end{array}$ & $\begin{array}{l}2.5 \mathrm{da} \\
\text { hrs pei }\end{array}$ \\
\hline $\begin{array}{l}\text { Song et al. } \\
2020^{a}\end{array}$ & China & $\begin{array}{l}\text { Elementary, Middle, } \\
\text { Secondary, College, } \\
\text { University teachers }\end{array}$ & 161 & 38.50 & NR & WL & $\begin{array}{l}\text { Mindfulness } \\
\text { Training }\end{array}$ & $\begin{array}{l}\text { Mindfulness } \\
\text { and/or } \\
\text { relaxation }\end{array}$ & $\begin{array}{l}\text { Adapted from } \\
\text { MBSR, including } \\
\text { psychoeducation, } \\
\text { sitting } \\
\text { meditation, } \\
\text { mindful eating, } \\
\text { body scan }\end{array}$ & $\begin{array}{l}4 \text { days } \\
\text { 8hrs } p \\
\text { day }\end{array}$ \\
\hline $\begin{array}{l}\text { Telles et al. } \\
2018^{*}\end{array}$ & India & Elementary teachers & 236 & 41.90 & 0.00 & $\mathrm{NI}$ & $\begin{array}{l}\text { Residential } \\
\text { Yoga Program }\end{array}$ & $\begin{array}{l}\text { Mindfulness } \\
\text { and/or } \\
\text { relaxation }\end{array}$ & $\begin{array}{l}\text { Physical postures } \\
\text { \& exercises, } \\
\text { breathing } \\
\text { techniques, } \\
\text { chanting, guided } \\
\text { relaxation }\end{array}$ & $\begin{array}{l}15 \text { day } \\
6 \text { hrs p } \\
\text { day }\end{array}$ \\
\hline $\begin{array}{l}\text { Thephilah et } \\
\text { al., } 2020\end{array}$ & India & Secondary teachers & 28 & NR & NR & NR & $\begin{array}{l}\text { Autogenic } \\
\text { Relaxation } \\
\text { Training }\end{array}$ & $\begin{array}{l}\text { Mindfulness } \\
\text { and/or } \\
\text { relaxation }\end{array}$ & $\begin{array}{l}\text { Relaxation } \\
\text { training, } \\
\text { including } \\
\text { psychoeducation }\end{array}$ & $\begin{array}{l}\text { 6-weet } \\
\text { 2-hr } \\
\text { sessio } \\
\text { deliver } \\
\text { weekly }\end{array}$ \\
\hline
\end{tabular}

\begin{tabular}{|c|c|c|c|c|c|c|c|c|c|c|}
\hline $\begin{array}{l}\text { Todd et al., } \\
2019\end{array}$ & $\begin{array}{l}\text { United } \\
\text { Kingdom }\end{array}$ & $\begin{array}{l}\text { Elementary \& } \\
\text { Secondary teachers }\end{array}$ & 44 & 41.25 & 66.67 & None & MBSR & $\begin{array}{l}\text { Mindfulness } \\
\text { and/or } \\
\text { relaxation }\end{array}$ & $\begin{array}{l}\text { Mindfulness } \\
\text { meditation, } \\
\text { including body } \\
\text { scan \& } \\
\text { awareness }\end{array}$ & $\begin{array}{l}\text { 8-week } \\
\text { eight } 2 \\
\text { sessio } \\
\text { deliver } \\
\text { weekly }\end{array}$ \\
\hline $\begin{array}{l}\text { Tsang et al. } \\
2015^{\star}\end{array}$ & $\begin{array}{l}\text { Hong } \\
\text { Kong }\end{array}$ & Elementary teachers & 93 & 38.43 & 21.28 & WL & $\begin{array}{l}\text { Stress } \\
\text { Management } \\
\text { Program }\end{array}$ & $\begin{array}{l}\text { Cognitive- } \\
\text { behavioural } \\
\text { skills }\end{array}$ & $\begin{array}{l}\text { Based on CBT \& } \\
\text { CAM, including } \\
\text { cognitive } \\
\text { restructuring, } \\
\text { self- } \\
\text { management, } \\
\text { relaxation, } \\
\text { mindfulness, } \\
\text { aromatherapy, } \\
\text { acupressure }\end{array}$ & $\begin{array}{l}\text { 6-weeh } \\
\text { 2-hr } \\
\text { sessio }\end{array}$ \\
\hline $\begin{array}{l}\text { Vesely et al. } \\
2014^{\star}\end{array}$ & Canada & Pre-service teachers & 49 & 26.50 & 0.00 & $\mathrm{NI}$ & $\begin{array}{l}\text { Managing } \\
\text { Occupational } \\
\text { Stress } \\
\text { through the } \\
\text { Development } \\
\text { of El }\end{array}$ & $\begin{array}{l}\text { Socio- } \\
\text { emotional, } \\
\text { relationship, } \\
\text { and/or } \\
\text { interpersonal } \\
\text { skills }\end{array}$ & $\begin{array}{l}\text { Based on } \\
\text { Swinburne El } \\
\text { Model, including } \\
\text { emotional self- } \\
\text { awareness \& } \\
\text { expression, } \\
\text { reasoning, self- } \\
\text { management, } \\
\text { management of } \\
\text { others, self- } \\
\text { control }\end{array}$ & $\begin{array}{l}\text { 5-week } \\
\text { five 1.! } \\
\text { sessio } \\
\text { deliver } \\
\text { weekly }\end{array}$ \\
\hline $\begin{array}{l}\text { Wimmer et al. } \\
2019 *, b\end{array}$ & Germany & Pre-service teachers & 154 & NR & 7.84 & $\begin{array}{l}\mathrm{NI}+ \\
\mathrm{AM}\end{array}$ & MBSR & Combination & $\begin{array}{l}\text { Mindfulness } \\
\text { meditation, } \\
\text { including body } \\
\text { scan \& } \\
\text { awareness, } \\
\text { including ACT } \\
\text { and Dialectical }\end{array}$ & $\begin{array}{l}\text { 12-wet } \\
\text { eight } 1 \\
\text { sessio } \\
\text { deliver } \\
\text { twice r } \\
\text { week }\end{array}$ \\
\hline
\end{tabular}




\begin{tabular}{|c|c|c|c|c|c|c|c|c|c|c|}
\hline & & & & & & & & & $\begin{array}{l}\text { Behaviour } \\
\text { Therapy }\end{array}$ & \\
\hline $\begin{array}{l}\text { Winzelberg \& } \\
\text { Luskin } 1999\end{array}$ & USA & Pre-service teachers & 21 & 24.50 & NR & WL & RISE Program & $\begin{array}{l}\text { Mindfulness } \\
\text { and/or } \\
\text { relaxation }\end{array}$ & $\begin{array}{l}\text { Psychoeducation, } \\
\text { guided } \\
\text { meditation \& } \\
\text { relaxation, } \\
\text { focusing } \\
\text { techniques }\end{array}$ & $\begin{array}{l}\text { 4-week } \\
\text { four } 4 ! \\
\text { sessio } \\
\text { deliver } \\
\text { weekly }\end{array}$ \\
\hline $\begin{array}{l}\text { Zadok-Gurman } \\
\text { et al. 2021* }\end{array}$ & Israel & $\begin{array}{l}\text { Teachers (type not } \\
\text { specified) }\end{array}$ & 67 & 45.00 & 8.57 & $\mathrm{NI}$ & IBSR & Combination & $\begin{array}{l}\text { Based on } \\
\text { principles and } \\
\text { skills of } \\
\text { observation, self- } \\
\text { exploration, } \\
\text { cognitive } \\
\text { reframing, and } \\
\text { empowerment. }\end{array}$ & $\begin{array}{l}20 \text {-we } \\
\text { ten } 2.5 \\
\text { biweek } \\
\text { group } \\
\text { meetir } \\
\text { and } \\
\text { biweet } \\
1.5-h r \\
\text { individ } \\
\text { sessio }\end{array}$ \\
\hline
\end{tabular}

Note. *=Studies included in the meta-analysis; ${ }^{\mathrm{a}}=$ includes samples other than teachers, including counsellors/psychologists, administrative staff, principals, parents, affiliated family consultants, managers, learning support etc. $N$, mean ages, and dropout reported in Table 1 for these studies include the whole sample; ${ }^{b=}$ These studies included more than one intervention group. Only the relevant intervention was selected for inclusion in this review and meta-analysis, which is reported in Table 1 (see "Program" column). The total sample sizes reported for these studies only include the relevant intervention and the control group/s. The mean ages and dropout reported in Table 1 for these studies only include the relevant groups if they were reported. NR=information not reported. $\mathbf{N}$ - Total number of participants allocated to groups. Mean Age - Mean age of the allocated sample at baseline, unless otherwise specified. Attrition Number of participants lost to drop out in the intervention group only, measured after the final follow up measurement time point. Control group - WL=wait-list control, $\mathrm{Nl}=$ no intervention control (including treatment as usual), None=a comparison group was used rather than a control group; $\mathrm{AMC}=\mathrm{attention}$ matched control. Program Content - MBI=Mindfulness-Based Intervention; MBSR=Mindfulness Based Stress Reduction; MBCT=Mindfulness Based Cognitive Therapy; RULER=Recognising, Understanding, Labeling, Expressing, and Regulating Emotion; MOM=Mindfulness-Oriented Meditation; SEL=Socio-Emotional Learning; PMR=Progressive Muscle Relaxation; CB-SMP=Cognitive Behavioural Stress Management Program; IBSR=Inquiry-Based Stress Reduction; CAM=Complementary and Alternative Medicine; El=Emotional Intelligence. Outcome Measures - PSS=Perceived Stress Scale; WEMWBS=Warwick-Edinburgh Mental Well-Being Scale; MBI-ES-EE=Maslach Burnout Inventory - Educator Survey - Emotional Exhaustion Subscale; MBI-EE=Maslach Burnout Inventory Emotional Exhaustion Subscale; BOJSM=Brief Overall Job Satisfaction Measure; GHQ-SS=General Health Questionnaire - Somatic Symptoms Subscale; GHQ-Al=General Health Questionnaire - Anxiety and Insomnia Subscale; GHQ-D=General Health Questionnaire - Depression Subscale; PSQI=Pittsburgh Sleep Quality Index; QSS=Quality of Sleep Scale; SWLS=Satisfaction with Life Scale; PANAS-P=Positive and Negative Affect Scale - Positive; PANAS-N=Positive and Negative Affect - Negative; RS=Resilience Scale; TSI=Teacher Stress Inventory; STAI-S=State-Trait Anxiety Inventory - State Subscale; BSI-D=Brief StresS Inventory - Depression Subscale; BSI-A=Brief Stress Inventory - Anxiety Subscale; BSI-S=Brief Stress Inventory - Somatisation Subscale; SSS=Subjective Stress Scale; AVEM-SW=Work-Related Behaviour and Experience Patterns - Satisfaction with Work; PSQ=Perceived Stress Questionnaire; HADS-D=Hospital Anxiety and Depression Scale - Depression Subscale; HADS-A=Hospital Anxiety and Depression Scale - Anxiety Subscale; CBI-WS=Copenhagen Burnout Inventory - Work Subscale; BAI=Beck Anxiety Inventory; SP-ESR=Stress Profile - Emotional Stress Reactions Subscale; SP-GW=Stress Profile - General Wellbeing Subscale; DASS-D=Depression Anxiety Stress Scale - Depression Subscale; DASS-A=Depression Anxiety Stress Scale - Anxiety Subscale; DASSS=Depression Anxiety Stress Scale - Stress Subscale; SRS=Stress Response Scale; BJSQ-D=Brief Job Stress Questionnaires - Depression Subscale; BJSQA=Brief Job Stress Questionnaires - Anxiety Subscale; BJSQ-SSR=Brief Job Stress Questionnaires - Somatic Stress Response Subscale; BJSQ-F=Brief Job Stress Questionnaires - Fatigue Subscale; ASSET-PW=An Organisational Stress Screening Tool - Psychological Well-being Scale; TSI-EM=Teacher Stress Inventory - Emotional Manifestations Subscale; TSI-FM=Teacher Stress Inventory - Fatigue Manifestations; OSI-MWS=Occupational Stress Indicator Mental Wellbeing Scale; OASIS=Overall Anxiety Severity and Impairment Scale; RSCA-A-R=Resiliency Scale for Children and Adolescence - Adult Version Revised - Emotional Reactivity Subscale; PERMA=Positive Emotion, Engagement, Relationships, Meaning, and Accomplishment scale; BRS=Brief Resilience Scale.

Table 3. ROB-II Judgments for each Domain 


\begin{tabular}{|c|c|c|c|c|c|c|}
\hline Authors & Randomisation & Deviation & Missing & Outcome & Reporting & Overall \\
\hline Ancona et al. 2014 & High & SC & Low & SC & SC & High \\
\hline Ansley et al. 2021 & SC & Low & High & SC & SC & High \\
\hline Au et al. 2016 & SC & High & SC & SC & SC & High \\
\hline Benn et al. 2012 & SC & Low & High & SC & SC & High \\
\hline Berger et al. 2016 & Low & SC & Low & SC & SC & $\mathrm{SC}$ \\
\hline Bertoch et al. 1989 & SC & SC & SC & SC & SC & SC \\
\hline Biglan et al. 2013 & SC & Low & Low & SC & SC & $\mathrm{SC}$ \\
\hline Castillo-Gualda et al. 2017 & SC & Low & Low & SC & SC & $\mathrm{SC}$ \\
\hline Cecil et al. 1990 & SC & Low & SC & SC & High & High \\
\hline Chan et al. 2013 & SC & Low & Low & Low & SC & SC \\
\hline Cheek et al. 2003 & SC & Low & High & Low & High & High \\
\hline Cook et al et al. 2017 & SC & Low & High & SC & SC & High \\
\hline Cooley et al. 1996 & SC & Low & High & SC & High & High \\
\hline De Carvalho et al. 2021 & Low & Low & Low & SC & SC & SC \\
\hline Dike et al. 2021 & Low & Low & Low & SC & SC & SC \\
\hline Ebert et al. 2014 & SC & Low & Low & SC & Low & SC \\
\hline Figl-Hertlein et al. 2014 & High & SC & High & SC & SC & High \\
\hline Flook et al. 2013 & SC & Low & High & SC & SC & High \\
\hline Franco et al. 2013 & SC & Low & High & SC & SC & High \\
\hline Grant et al. 2010 & SC & Low & High & SC & SC & High \\
\hline Harris et al. 2016 & High & Low & Low & SC & SC & High \\
\hline Hwang et al. 2019 & High & Low & High & High & SC & High \\
\hline Igbokwe et al. 2019 & SC & SC & Low & SC & SC & $\mathrm{SC}$ \\
\hline Jeffcoat et al. 2012 & Low & Low & Low & SC & SC & SC \\
\hline Jennings et al. 2011 & SC & SC & Low & SC & SC & $\mathrm{SC}$ \\
\hline Jennings et al. 2013 & SC & SC & Low & SC & SC & $\mathrm{SC}$ \\
\hline Jennings et al. 2017 & Low & SC & Low & SC & SC & $\mathrm{SC}$ \\
\hline Jennings et al. 2019 & Low & SC & Low & SC & $\mathrm{SC}$ & $\mathrm{SC}$ \\
\hline Kaspereen et al. 2012 & Low & SC & SC & SC & SC & $\mathrm{SC}$ \\
\hline Montero-Marin et al. 2021 & SC & Low & Low & SC & SC & SC \\
\hline Nwabuko et al. 2019 & Low & SC & High & $\mathrm{SC}$ & $\mathrm{SC}$ & High \\
\hline Ogba et al 2020 & Low & Low & Low & SC & SC & $\mathrm{SC}$ \\
\hline Onuigbo et al. 2018 & Low & SC & Low & SC & SC & SC \\
\hline Pozo-Rico et al. 2021 & $\mathrm{SC}$ & High & High & SC & SC & High \\
\hline Rao et al. 2017 & Low & SC & Low & SC & SC & $\mathrm{SC}$ \\
\hline Roeser et al. 2013 & High & SC & Low & High & SC & High \\
\hline Schloss et al. 1983 & SC & SC & High & SC & SC & High \\
\hline Schoeps et al. 2019 & High & SC & High & SC & SC & High \\
\hline Sharp et al. 1985 & High & SC & High & SC & SC & High \\
\hline Sottimano et al. 2018 & $\mathrm{SC}$ & Low & Low & SC & SC & $\mathrm{SC}$ \\
\hline Tunnecliffe et al. 1986 & High & SC & High & SC & SC & High \\
\hline Tsang et al. 2021 & SC & Low & Low & SC & SC & SC \\
\hline Ugwoke et al. 2018 & Low & Low & Low & SC & Low & SC \\
\hline
\end{tabular}




\begin{tabular}{|lllllll|}
\hline Unterbrink et al 2012 & Low & High & High & SC & SC & High \\
\hline Wu et al. 2006 & SC & SC & High & SC & SC & High \\
\hline Zolnierczyk-Zreda et al. 2005 & SC & SC & Low & SC & SC & SC \\
\hline
\end{tabular}

Note. $\mathrm{SC}=$ some concerns.

Table 4. ROBINS-I Risk of Bias Judgments for each Domain

\begin{tabular}{|c|c|c|c|c|c|c|c|}
\hline Authors & Confounding & Selection & Deviation & Missing & Outcomes & Reporting & Overall \\
\hline Berkovich-Ohana et al. 2020 & Serious & Low & Low & $\mathrm{NI}$ & Serious & Serious & Serious \\
\hline Beshai et al. 2015 & Moderate & Low & Low & Serious & Serious & Low & Serious \\
\hline Carroll et al. 2021 & Moderate & Low & Low & Low & Serious & Low & Serious \\
\hline Castillo-Guialda et al. 2019 & Moderate & Low & Low & Low & Serious & Serious & Serious \\
\hline Cicotto et al. 2014 & Serious & Low & Low & Low & Serious & Serious & Serious \\
\hline Cheng et al. 2021 & Serious & Low & Low & Low & Serious & Low & Serious \\
\hline Dahal \& Pradhan 2018 & Moderate & Low & Low & $\mathrm{NI}$ & Serious & Low & Serious \\
\hline de Souza et al. 2016 & Serious & Low & Low & Serious & Serious & Serious & Serious \\
\hline Dicke et al. 2015 & Moderate & Low & Low & Low & Serious & Low & Serious \\
\hline Dyer et al. 2020 & Serious & Low & Low & Serious & Low & Serious & Serious \\
\hline Fabbro et al. 2020 & Serious & Low & Low & Low & Serious & Low & Serious \\
\hline Forman 1982 & Serious & Low & Low & Serious & Serious & Moderate & Serious \\
\hline Frank et al., 2015 & Moderate & Low & Low & $\mathrm{NI}$ & Serious & Low & Serious \\
\hline Friedman et al., 1983 & Moderate & Low & Low & $\mathrm{NI}$ & Serious & Serious & Serious \\
\hline Goetz et al. 2013 & Moderate & Low & Low & Serious & Serious & Low & Serious \\
\hline Gouda et al., 2016 & Moderate & Low & Low & Low & Serious & Low & Serious \\
\hline Hall et al., 1997 & Serious & Low & Low & Low & Serious & Serious & Serious \\
\hline Johnson \& Naidoo 2017 & Moderate & Low & Low & Low & Serious & Low & Serious \\
\hline Johnson \& Naidoo 2013 & Moderate & Low & Low & Low & Serious & Serious & Serious \\
\hline Larsson et al. 1990 & Serious & Low & Low & Serious & Serious & Serious & Serious \\
\hline Leung et al. 2011 & Moderate & Low & Low & Critical & Serious & Serious & Critical \\
\hline Luong et al. 2019 & Moderate & Low & Low & Low & Serious & Low & Serious \\
\hline Mahmoodabad et al. 2014 & Moderate & Low & Low & $\mathrm{NI}$ & Serious & Serious & Serious \\
\hline Miyahara et al., 2017 & Serious & Low & Low & Low & Serious & Low & Serious \\
\hline Munday et al., 1995 & Serious & Low & Low & $\mathrm{NI}$ & Serious & Serious & Serious \\
\hline Schnaider-Levi et al. 2020 & Moderate & Low & Low & $\mathrm{NI}$ & Serious & Low & Serious \\
\hline Shimazu et al. 2003 & Serious & Low & Low & Serious & Serious & Low & Serious \\
\hline Siu et al 2014 & Critical & Low & Low & Low & Serious & Serious & Critical \\
\hline Song et al. 2020 & Serious & Low & Low & $\mathrm{NI}$ & Serious & Serious & Serious \\
\hline Telles et al. 2018 & Serious & Low & Low & Low & Serious & Serious & Serious \\
\hline Thephilah et al., 2020 & Serious & Low & Low & $\mathrm{NI}$ & Serious & Critical & Critical \\
\hline Todd et al., 2019 & Serious & Low & Low & Serious & Serious & Low & Serious \\
\hline Tsang et al. 2015 & Moderate & Low & Low & Low & Serious & Low & Serious \\
\hline Vesely et al. 2014 & Serious & Low & Low & Low & Serious & Serious & Serious \\
\hline Wimmer et al. 2019 & Moderate & Low & Low & Serious & Serious & Low & Serious \\
\hline Winzelberg \& Luskin 1999 & Serious & Low & Low & Moderate & Serious & Serious & Serious \\
\hline Zadok-Gurman et al. 2021 & Moderate & Low & Low & Moderate & Serious & Low & Serious \\
\hline
\end{tabular}

Page 27/29 
Note. $\mathrm{Nl}=$ no information.

Table 5. RCT Heterogeneity Statistics for the Primary Analyses at Post-Intervention

\begin{tabular}{|lllllll|}
\hline \multicolumn{7}{l}{ Heterogeneity Statistics } \\
\cline { 2 - 7 } & $Q$ & $d f$ & $p$ & $R$ & $\mathrm{Cl}_{\text {lower }}$ & $\mathrm{Cl}_{\text {upper }}$ \\
\hline Primary Outcomes & & & & & & \\
Depression & 1.07 & 2 & .59 & 0.00 & 0.00 & 93.72 \\
\hline Anxiety & 1.93 & 1 & .17 & 48.21 & - & - \\
\hline Stress & 98.66 & 7 & $<.001$ & 92.91 & 88.34 & 96.68 \\
Psychological distress & 51.23 & 1 & $<.001$ & 98.05 & - & - \\
\hline Burnout & 38.64 & 8 & $<.001$ & 79.23 & 61.22 & 88.95 \\
\hline Wellbeing & 9.06 & 3 & .03 & 66.90 & 3.27 & 88.67 \\
\hline
\end{tabular}

Note. Confidence interval estimates cannot be calculated when $d f<2$.

Table 6. Non-Randomised Controlled Trial Heterogeneity Statistics for the Primary Analyses at Post-Intervention

\begin{tabular}{|lllllll|}
\hline \multicolumn{7}{|c|}{ Heterogeneity Statistics } \\
\cline { 2 - 7 } & $Q$ & $d f$ & $P$ & $R$ & $\mathrm{Cl}_{\text {lower }}$ & $\mathrm{Cl}_{\text {upper }}$ \\
\hline Primary Outcomes & & & & & \\
\hline Depression & 8.37 & 5 & .14 & 40.28 & 0.00 & 76.32 \\
\hline Anxiety & 19.08 & 8 & .01 & 58.08 & 12.19 & 79.98 \\
\hline Stress & 18.94 & 8 & .02 & 57.77 & 11.44 & 79.85 \\
\hline Burnout & 3.92 & 3 & .37 & 23.40 & 0.00 & 69.73 \\
\hline Wellbeing & 10.49 & 6 & .08 & 42.82 & 0.00 & 75.96 \\
\hline Somatisation & 6.44 & 1 & .01 & 84.47 & - & - \\
\hline
\end{tabular}

Note. Confidence interval estimates cannot be calculated when $d f<2$.

\section{Figures}



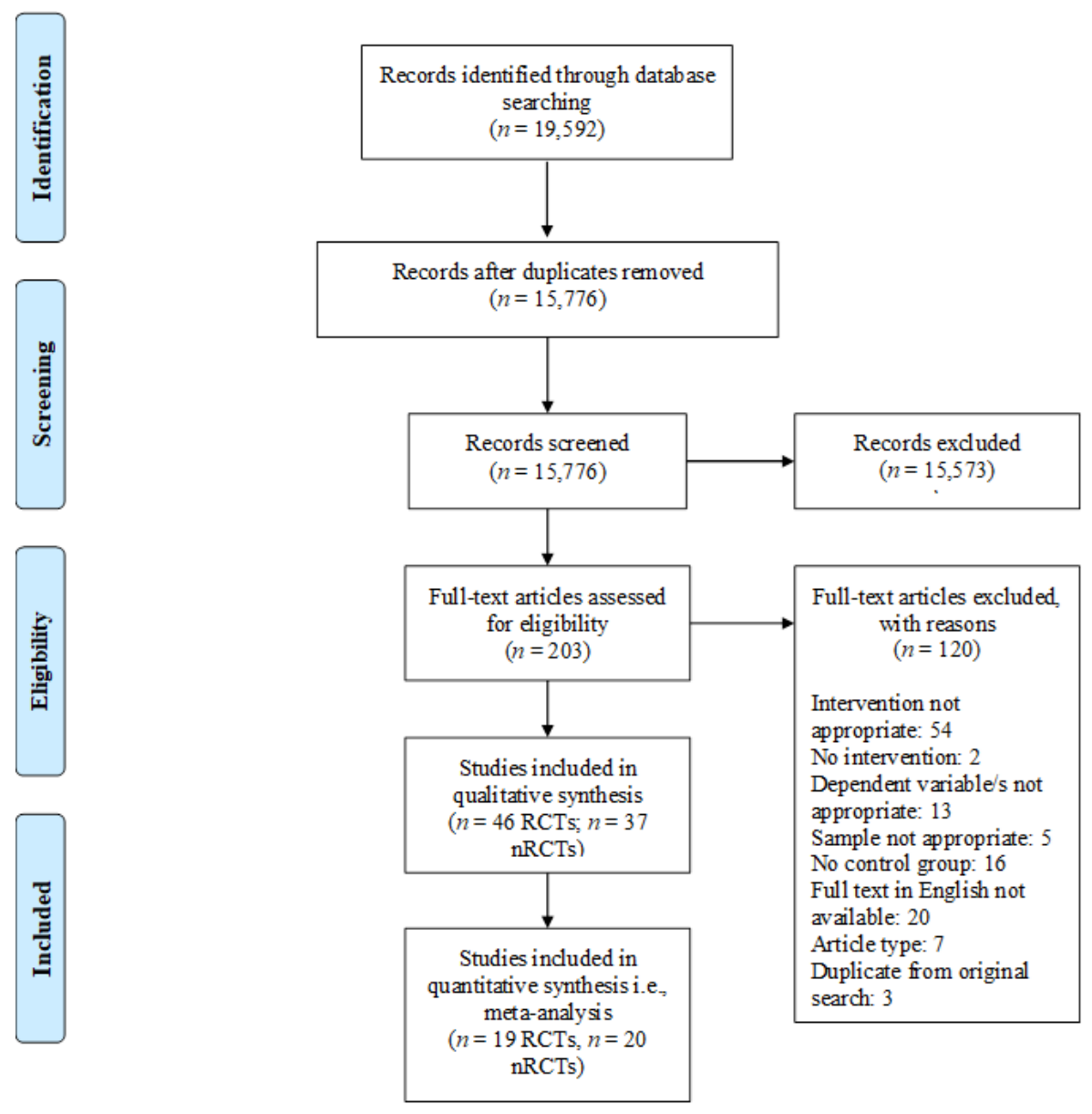

Figure 1

PRISMA Flow Diagram

\section{Supplementary Files}

This is a list of supplementary files associated with this preprint. Click to download.

- Appendix.docx 